NBER WORKING PAPER SERIES

\title{
ORGANIZATION STRUCTURE AND \\ CREDIBILITY: EVIDENCE FROM \\ COMMERCIAL BANK SECURITIES \\ ACTIVITIES BEFORE THE GLASS- \\ STEAGALL ACT
}

Randall S. Kroszner

Raghuram G. Rajan

Working Paper 5256

\section{NATIONAL BUREAU OF ECONOMIC RESEARCH 1050 Massachusetts Avenue \\ Cambridge, MA 02138 \\ September 1995}

Thanks to George Benston, Eugene Fama, Robert Gertner, Charlie Himmelberg, George Kaufman, Geoffrey Miller, Mitchell Petersen, Manju Puri, Andrei Shleifer, Philip Strahan for helpful comments and to Andy Curtis, Steve Sandberg, and Jim Stoker for research assistance. Research support from the National Science Foundation and the Graduate School of Business of the University of Chicago is gratefully acknowledged. This paper is part of NBER's research program in Corporate Finance. Any opinions expressed are those of the authors and not those of the National Bureau of Economic Research.

(C) 1995 by Randall S. Kroszner and Raghuram G. Rajan. All rights reserved. Short sections of text, not to exceed two paragraphs, may be quoted without explicit permission provided that full credit, including (c) notice, is given to the source. 


\title{
ORGANIZATION STRUCTURE AND \\ CREDIBILITY: EVIDENCE FROM \\ COMMERCIAL BANK SECURITIES \\ ACTIVITIES BEFORE THE GLASS- \\ STEAGALL ACT
}

\begin{abstract}
This paper investigates how organizational structure can affect a firm's ability to compete. In particular, we examine the two ways in which U.S. commercial banks organized their investment banking operations before the 1933 Glass-Steagall Act forced the banks to leave the securities business: as an internal securities department within the bank and as a separately incorporated and capitalized securities affiliate. We document a strong movement toward the use of the affiliate structure during the 1920s, and regulation does not appear to explain this evolution. While departments underwrote seemingly higher quality firms and securities than did comparable affiliates, the departments obtained lower prices for the issues they underwrote. This evidence is consistent with the hypothesis that there was a perception of potential conflicts of interest when lending and underwriting were closely combined in the departmental structure. We find evidence that bank managers during this period were concerned about such perceptions. We then develop further tests to support the view that by distancing underwriting activities from lending operations, banks could more credibly certify the quality of the issues they underwrote, thereby obtaining higher prices for them. Our results suggest that internal organization may indeed affect the activities and effectiveness of a firm. They also suggest that bank regulators' interest in "firewalls" between commercial and investment banking may be reasonable, but that the market may propel banks to adopt an internal structure that would address regulators' concerns.
\end{abstract}

Randall S. Kroszner

Graduate School of Business

University of Chicago

1101 East 58th Street

Chicago, IL 60637
Raghuram G. Rajan

Graduate School of Business

University of Chicago

1101 East 58th Street

Chicago, IL 60637

and NBER 
How does the organizational structure of a financial services firm affect its ability to compete in the various markets in which it operates? ${ }^{1}$ The way an enterprise is structured to undertake different activities may influence the incentives and resources of its constituent divisions, as well as the relationship between them. Furthermore, theorists have argued that the ability of third parties such as regulators and public investors to monitor and control the divisions may be affected through appropriate structuring. To the extent that organizational structure matters, it could be a means by which the management of an enterprise binds its hands and commits to a set of business practices. ${ }^{2}$ Although there has been little empirical investigation of such theories, bank regulators throughout the world appear to believe that the internal organization of banks matters, since they have mandated specific structures for bank involvement in certain activities. ${ }^{3}$ Whether structure matters, and if so, whether it needs to be mandated, are issues of importance to both academics and policy makers.

In this paper, we investigate whether organization structure matters when commercial banks add investment banking activities, such as securities underwriting, to their traditional lending and deposittaking roles. Prior to 1933, depository institutions in the U.S. could engage in investment banking. Subsequently, section 20 of the 1933 Glass-Steagall Act has prohibited commercial banks from direct

\footnotetext{
' By organization structure, we mean the way the different activities undertaken by the organization are formally linked. One aspect of organizational structure is hierarchy: Does the manager of the division undertaking one activity report to the manager of the division undertaking another? There are other aspects also: Are the divisions separately capitalized? Do they have a common name/reputation? Do they have common supervisors or boards of directors? Can they independently raise and allocate capital or is there a common allocation process?, etc. We will be more specific about the aspects of organizational structure that we investigate shortly.

${ }^{2}$ A number of studies examine the impact of organizational structure on incentives. For the theories, see for example, Alchian and Demsetz (1972), Fama and Jensen (1983a, 1983b), Milgrom and Roberts (1992), and Rotemberg and Saloner (1994), Williamson (1975, 1985), and the articles in Putterman and Kroszner (forthcoming). Empirical work has largely examined the relative efficiency or behavior of different types of ownership forms and attempted to relate it back to the theories. For example, see the work on stock versus mutual financial firms ( $O^{\prime}$ Hara 1981, Mayers and Smith 1988, 1990). Little work has been done on how the internal organization of a firm affects its behavior and performance, and what has been done tends to be descriptive (for example, Chandler 1977).

${ }^{3}$ In Japan, the United Kingdom, and Canada, for example, commercial banks recently have been permitted to enter the securities business but only through a separately incorporated and capitalized subsidiary of the commercial bank (see Dale 1993). We discuss changes in U.S. banking regulation in detail below.
} 
involvement in corporate securities underwriting or dealing, and from affiliating with any organization "engaged principally" in such activities. During the last decade, the U.S. Congress (including the current Congress) has debated extensively the repeal of the Glass-Steagall Act. One of the key points of controversy has been the nature and extent of the structural separations or "firewalls" between traditional commercial banking operations and investment banking operations (see Kroszner and Stratmann 1995). While awaiting the repeal of the act, since 1989 the Federal Reserve and the Office of the Comptroller of the Currency have given a more flexible interpretation to the Act and authorized selected banks to set

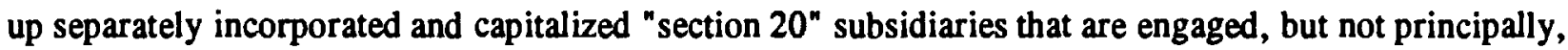
in the otherwise forbidden securities activities (see Macey and Miller 1992a, pp. 491-571). ${ }^{4}$ The organizational form allowed thus far for "universal banking" in the United States therefore contrasts with the classic German universal bank in which the securities business is tightly integrated into the bank itself.

Regulators in the United States have cited two main reasons for mandating "an insulating framework" between a commercial bank and its securities activities (Greenspan 1988). First, commingling of lending and underwriting could lead to "conflicts of interest and loss of public confidence" (Greenspan 1988). If, for example, a client firm's prospects deteriorate without the public realizing it, a commercial bank may attempt to persuade its underwriting operation to bring out a public issue on behalf of the firm and use the proceeds to repay the firm's outstanding bank loans, without fully disclosing its adverse information about the firm's prospects. If the public then has unexpectedly poor returns on its investments, the bad experience could lead to a loss of confidence in the integrity of public markets and, perhaps, in the banking system itself. The regulators appear to believe that distancing the bank's securities operation from its lending operation can mitigate the potential conflicts between the bank as a lender and as an impartial certifier of securities and, thereby, improve the public's perception about the

\footnotetext{
${ }^{4}$ Currently, no more than 10 percent of total revenues in the subsidiary may stem from the otherwise forbidden investment banking activities. See Blair (1994).
} 
integrity of the banks and securities markets. ${ }^{3}$ A second concern is risk: when a bank's securities operation is closely coupled with its lending operation, shocks to either will be transmitted to the market the other operates in. Furthermore, the banks may attempt to expand (implicitly or explicitly) federal deposit insurance to cover their securities activities. The consequent moral hazard problems, e.g., because a bank may be "too big to fail," could lead to excessive risk-taking by the banks in the new activities.

These arguments are not sufficient for the conclusion that structure should be regulated. If the potential conflicts of interest from commingled activities are seen by the intermediary's customers as important, it will raise the intermediary's cost of doing business. If financial markets are competitive, the intermediary will trade off these costs with the potential gains from scope economies through joint activities and voluntarily adopt the most appropriate structure. ${ }^{6}$ Of course, the externalities created by government deposit insurance may distort this choice -- but this suggests diminishing the impact of deposit insurance by, for example, allowing only well-capitalized banks into the securities business rather than requiring structural separation. To make the case for regulation of structure, it should be shown empirically, first, that organizational structure matters and, second, that banks do not make the appropriate choice when free to choose.

Unfortunately, we do not have enough cross-sectional variation in the structure of universal banks within any country today to be able to address the issue. Comparing bank performance across countries is problematic because it is difficult to correct for differences due to macroeconomic shocks, the nature of markets and institutions, and other regulations besides those directly relating to universal banking.

\footnotetext{
${ }^{5}$ Conflicts of interest have to do with the enhanced incentive for moral hazard or adverse selection stemming from a particular organizational form. Of course, conflicts of interest are never completely absent in any business organization; it is the relative degree that matters. Arguments about conflicts of interest are important not only today, but also during the debates over the Glass-Steagall Act in the 1930s (see Kroszner and Rajan 1994).

${ }^{6}$ Rajan (1994) shows that if financial markets are not competitive, banks may not choose the efficient structure.
} 
History, however, offers a fertile testing ground. Prior to the Glass-Steagall Act of 1933, commercial banks in the United States underwrote securities through both internal securities department and separately incorporated and capitalized affiliates. These competing structures are close analogues of the classic

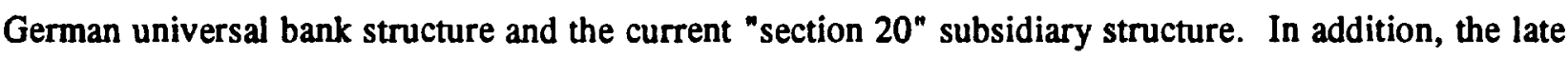
1920s was a period when banks can and did fail because deposit insurance -- both explicit and implicit - was virtually non-existent. ${ }^{7}$ This enables us to focus on the choice of organization structure in an environment free of the distortionary influences of deposit insurance. From a public policy standpoint, the virtue of abstracting from the deposit insurance argument issue is not that it is unimportant, but that its consequences, as well as measures to deal with them, are relatively well explored (e.g., Kane 1989 and Kroszner and Strahan 1995). Less well-known is the empirical magnitude of the costs and benefits of different ways of structuring universal banks which is the focus of our study.

Section I describes the types of structures that U.S. commercial banks adopted as they became involved in the securities business during the 1920s. Over the decade, depository institutions moved away from the internal department organization towards the separately capitalized securities affiliate. We investigate a number of possible regulatory explanations for this trend but find that they cannot explain this movement. Instead, the structural evolution appears to reflect the private choices by the banks given their experiences with the different forms.

A primary function of an underwriter is to certify and place public issues with investors. We investigate whether there were differences in the kinds of issues the two structures underwrote and how effective they were in carrying out their certification function. One measure of effectiveness for an underwriter is the prices obtained for securities. In section II, we find that, ceteris paribus, affiliates obtained higher prices for the securities they underwrote than did internal departments.

\footnotetext{
${ }^{7}$ While some states had adopted various forms of voluntary or mandated deposit insurance, these schemes had either collapsed before, or were moribund by, the late 1920s (see White 1983).
} 
To link this phenomenon to structure, we first go back to contemporary accounts of structural choice. In section III, we provide direct, but anecdotal, evidence from the 1920s suggesting that the public's perception about conflicts of interest in banks was an important factor in banks' decisions about their internal structure. Banks appeared to believe that they could improve their credibility and effectiveness by distancing two activities with potential conflicts of interest. If the public believed this, it would explain why affiliate underwritten issues (where the distance in terms of managerial control and cash flows between the lending and underwriting operations was larger than with internal departments) obtained higher prices than department underwritten issues.

In section IV, we investigate additional implications suggested by the theory if the public associated greater uncertainty with issues underwritten by departments. We find that relative to comparable affiliates, the departments underwrote informationally-less-sensitive securities for safer firms. Such a specialization is a natural response to a suspicious public. Moreover, smaller departments were subject to a greater discount (relative to comparable affiliates) than were larger departments and specialized more. Other, more continuous, measures of closeness of lending and underwriting activities, such as the degree of overlap between the bank board and the affiliate board, are positively correlated with the size of the discount imposed on the issues underwritten. Issues whose stated purpose is to repay debt are subject to a larger discount, especially if the underwriter is a department. Finally, despite their observably higher ex ante quality, department underwritten issues default more frequently, suggesting that some discounting of these issues the public may have been merited. These results suggest that the greater credibility of banks underwriting through separate affiliates can account for the growth of the affiliate form during the 1920 s. Section V briefly summarizes our results and conclusions. 


\section{Evolution of Commercial Bank Involvement in the Securities Business during the 1920s}

\subsection{Organizational Forms}

Prior to the Glass-Steagall Act, commercial banks entered the securities business primarily through one of two organizational forms (see Peach 1941, Carosso 1970, and White 1986). The first was a "captive" internal securities department within the commercial bank. This structure is much like that of classic German universal banks in which investment banking and commercial banking operations coexist as departments inside the bank (see, e.g., Edwards and Fischer 1994 and Calomiris 1995). The second was to organize a separately capitalized and separately incorporated securities affiliate. ${ }^{8}$ There were a number of differences between affiliates and in-house departments. First, affiliates were chartered under state laws as regular limited liability corporations. Affiliate securities activities thus could be isolated from bank balance sheets. The capital buffer should, however, not be overstated: there were no minimum capital regulations, and some affiliates were incorporated with small amounts of capital (see, e.g., Peach 1941, p.81).9 Second, the affiliates, as regular corporations, were free from restrictions imposed on banks. Internal securities departments, on the other hand, were an integral part of the regulated bank. Third, since the affiliate was a separate corporation, it had its own board and officers. The degree of autonomy from the bank varied. For some affiliates, the directors and officers of the bank constituted only a minority of the directors and officers of the affiliate, while for others the management control was more complete (see Preston and Findlay 1930a and 1930b, Peach 1941, and Carosso 1970).

\footnotetext{
8 The specific legal organization of the affiliates could take a number of forms. First, each shareholder of the bank also would be a shareholder of the affiliate. Second, the stock of the affiliate would be held by another affiliate or by a holding company which also owned the stock of the commercial bank. Third, the bank would appoint of panel of trustees who would hold the shares of the affiliate in trust for the bank. Fourth, the bank would directly own the stock of the affiliate as an investment. See Preston and Findlay (1930a and 1930b), Moore (1934), Peach (1941), Edwards (1942), Carosso (1970), and White (1986).

9 Affiliates often reported separate balance sheets, so their condition can be isolated from the condition of the banks. For the 15 affiliates in our sample for which the Moody's Bankine and Finance Manual contained separate balance sheets, the mean capital of affiliates is 15 percent of their parent bank's capital. The range is from 4 percent to 43 percent.
} 
The affiliates were not, of course, completely isolated from the banks. Since the affiliates typically shared the name of their parent, affiliates enjoyed the "... benefit of the goodwill of their parent banks" (Peach 1941, p.52).

State-chartered and nationally-chartered depository institutions had somewhat different legal frameworks for engaging in a variety of financial services. While regulations on the internal activities of state-chartered institutions differed across the states, they generally faced little, if any, restriction on the organization of their securities activities (Peach 1941, pp.44-51). The National Banking Act of 1864 did not permit national banks to handle common stocks but left ambiguous their powers with respect to corporate bonds. Despite this legal cloud, many national banks did operate active internal securities departments. ${ }^{10}$ The McFadden Act of 1927 explicitly authorized the national banks to deal in and underwrite "investment securities" through internal securities departments. As Kaufman and Mote (1990) demonstrate, however, this provision was nothing more than a codification of the common, existing practice. $^{11}$

The 1920s saw a dramatic increase in the extent of bank and trust involvement in non-bank activities, either directly or through affiliates (see Kroszner and Rajan 1994). This movement was at least in part motivated by increasing disintermediation during the decade, with a growing number of firms turning to the capital markets to finance their operations and investment (see Kroszner 1995). ${ }^{12}$ Peach (1941, p.83) reports that the number of national banks operating securities affiliates, although not

10 Kaufman and Mote (1992) have laid to rest the unfounded assertion that a 1902 ruling by the Comptroller of the Currency forced national banks to transfer corporate securities activities from internal securities departments to separate securities affiliates.

I Kaufman and Mote (1990, p.393) provide the following quotation from the Senate and House Reports accompanying the McFadden Act: "this [securities dealing and underwriting] is a business that is regularly carried on by state banks and trust companies and has been engaged in by national banks for a number of years. The effect of this provision, therefore, is primarily regulative."

${ }^{12}$ Evaluating the entry of commercial banks during the 1920 s into "financial emporiums, " White $(1984$, p.102) concludes "... banks' new financial services were not begun as part of a speculative lark ... [but] represented a move by these firms to offset the decline of their traditional business..." 
necessarily underwriting securities, rose from 10 in 1922 to a peak of 114 in 1931 . The number of banks engaged in the securities business through their securities departments doubled from 62 to 123 during this period.

Table 1, from Charles E. Mitchell's testimony in 1931 (US Senate 1931, p.299), provides information on the roles of different types of underwriters in the securities markets of the late 1920s. The commercial banks were eroding the market share of independent investment banks in the bond underwriting business. Commercial banks underwrote roughly 22 percent of this market in 1927 and 45 percent by 1929. Separate affiliates were becoming the dominant organizational form for commercial bank underwriting. In particular, the share of bonds underwritten by separate affiliates of commercial banks tripled between 1927 and 1929, while the share underwritten through the securities departments of the banks fell by half. For these three years, separate affiliates underwrote three-quarters of the total volume of issues underwritten by commercial banks' securities departments and affiliates.

\subsection{The Evolution of the Organizational Forms}

To investigate the organizational choice in more detail, we use a variety of contemporary and more recent sources to identify commercial banks engaged in investment banking prior to the GlassSteagall Act: Preston and Findlay (1930a and 1930b), Moore (1934), Peach (1941), Carosso (1970), and White (1986), the Commercial and Financial Chronicle (CFC) and the National Securities Dealers of North America (1929). To be included in our sample, the bank or trust must be listed in the Moody's Banking Manual. Moody's provides information on each depository institution's charter, balance sheet, and the organization of the securities operations. ${ }^{13}$

In order to determine which of these banks were actively involved in securities underwriting, as opposed to simply acting as brokers, we examine the two-volume American Underwriting Houses and Their Issues (1928 and 1930). This source groups by underwriter all new public securities issued

\footnotetext{
${ }^{13}$ Moody's reports a separate balance sheet for some, but not all, affiliates.
} 
between January 1, 1925 and December 31, 1929 and provides information on the characteristics of the securities. Securities for which a house was the lead underwriter or syndicate manager are in bold and the house's name is listed first, if more than one house is involved. We include in our sample only those securities in which the commercial bank, trust, or its securities affiliate is the lead underwriter or syndicate manager. This process yields a total of 906 securities underwritten by 43 commercial banks and trusts through internal departments and 32 securities affiliates. ${ }^{14}$

Table 2A shows that in 1925 the number of securities underwritten by depository institutions was evenly divided between the two organizational forms. As the 1920s progress, the share of securities underwritten through internal departments steadily declines as affiliates increase in popularity. By 1929, underwriting through internal departments drops to 18 percent of securities underwritten by depository institutions. To check whether this result was part of a longer term trend, we examined the monthly "new capital flotations" section of the Commercial and Financial Chronicle (CFC) to collect the number of issues underwritten by these two forms for 1921. Fifty-seven percent of the securities underwritten by depository institutions were done through the department form, so the loss in market share for departments appears to be a persistent trend throughout the 1920 s.

\subsection{Can Regulation Account for the Evolution of Organizational Forms?}

Since the national and state banks faced somewhat different regulatory treatment of their securities operations, we should examine their choices separately to see whether regulation can account for the overall trend toward the affiliates. Table $2 \mathrm{~B}$ describes the changes in organizational form of underwriting by depository institutions with state and national charters. While there is only a slight downward trend in issues underwritten through departments of national banks, the vast majority of the issues underwritten

\footnotetext{
${ }^{14}$ Note that we have eight cases in which a bank underwrote first through a department and later in the sample period switched to an affiliate structure. In the totals reported here, securities underwritten by the bank when underwriting through a department are counted with the department totals, and similarly when underwriting through an affiliate. We discuss the "switchers" in more detail below.
} 
by national banks were through arm's length affiliates throughout the sample period. The McFadden Act of 1927 , which made internal securities operations explicitly permissible, does not appear to have an important impact on the manner in which the national banks organized their securities activities, thereby confirming the interpretation of the Act as doing nothing more than codifying existing practice (Kaufman and Mote 1990). Since the share of underwriting through departments does not rise after 1927 , the national banks do not appear to have been constrained in their organizational choice by the legal uncertainty of internal securities operations before McFadden.

The state-chartered institutions do increase their use of the affiliate structure during our sample period: the share of securities they underwrite through affiliates grows from roughly 40 percent to nearly 70 percent between 1925 and 1929 . State banks and trusts generally faced no regulatory constraints on their securities activities, and contemporary sources do not report any regulatory changes that would have resulted in this organizational change.

The evolution away from departments and towards affiliates occurred in three ways. First, new entrants into the securities business disproportionately adopted the affiliate form. ${ }^{15}$ Second, existing departments switched to the affiliate form. We found no examples of institutions that switched from using the affiliate form to using an internal department for their securities operations. Of the eight institutions that switched from department to affiliate, three had national charters and five had state charters, so both types of banks switched. Third, the increase in market share of the affiliates also took place through a relative reduction in business done by existing departments. The six departments that underwrote throughout 1925 to 1929 went from underwriting an average of 3.2 issues per year in 1925 to 1.8 issues per year in 1929. The eight affiliates who underwrote throughout, however, slightly increased their

\footnotetext{
is The entry numbers should be treated as suggestive. Since we do not have founding dates for all underwriters, we define a firm to have entered in 1929, for example, if it underwrites in 1929 but not in the period 1925-1928. Of the firms who entered in 1929 , for instance, 75 percent did so using affiliates even though 58 percent of the incumbents in 1928 were departments.
} 
business from 9.5 issues to 10 issues.

Another potential regulatory-based explanation concerns restrictions on branching. Since affiliates were not treated as branches of depository institutions, they were not subject to the locational limitations that banks and their branches faced. Most states did have some form of branching restriction. These regulations ranged from the extreme of "unit banking," which prohibited all branching, to limitations on the number and/or location of branches within the state, typically restricting branches to the same city or county (see White 1983). Potentially, affiliates could have been a way to evade or relax these geographical constraints, although affiliates could not legally be engaged in traditional banking functions of taking deposits and making loans.

If the evasion of branching restrictions were an important factor motivating the banks to open affiliates, the popularity of affiliates relative to departments should be directly related to the restrictiveness of the anti-branching statutes in each state. To test this hypothesis, we categorize states as (a) unlimited branching, (b) limited branching, and (c) branching prohibited, using the classification from the Federal Reserve Board (Federal Reserve Bulletin 1930). We then compare the relative frequency of departments and affiliates. The results in Table $3 \mathrm{~A}$ do not support the evasion of branching restrictions as an important factor in determining the way banks structured their securities operations. The chi-squared test cannot reject the null hypothesis of no difference between the distribution of affiliates and departments in states with different branching restrictions. ${ }^{16}$ In addition, the table shows that the affiliate structure tends to be relatively more frequent in states with no branching restrictions and less frequent where branching is prohibited. These relationships are the opposite of what one would expect if affiliates were

\footnotetext{
${ }^{16}$ We also ran a logit regression in which the dependent variable is a zero-one indicator for whether the affiliate structure was chosen. The independent variables included two indicators for branching status (e.g., full and limited) as well as characteristics of the depository institution (e.g., an indicator for national versus state charter, the log of the total assets of the institution, and the capital to asset ratio). The coefficients of the branching status indicators were small and statistically insignificant. National banks and large banks were more likely, however, to choose the affiliate form.
} 
used to escape anti-branching laws.

In Table 3B, we examine national and state institutions separately, because before the 1927 McFadden Act national banks generally faced more restrictions on intra-state branching than statechartered institutions in the same states (see White 1983). Again, escaping branching restrictions does not appear to have been an important factor for either the state or the nationally-chartered banks. The McFadden Act gave national banks branching powers almost equal to those of the state-chartered banks in the states in which they were located. Since this Act did not reverse the trend towards affiliates, it suggests again that branching does not appear to have been an important factor in the national banks' choice of the affiliate structure.

We also can investigate the branching restriction hypothesis by examining the actual locational choices of the affiliates. Most securities affiliates had a single office in the same city - typically along the same street -- as the parent bank. Only a few of the largest affiliates had offices outside of the home state of the parent bank, just as only a few of the largest independent investment banks had offices in multiple states. ${ }^{17}$ Finally, there was little change in branching statutes during the 1925 to 1929 period, and the few changes that did occur involved a relaxation of branching restrictions Federal Reserve Bulletin 1930). Branching restrictions, thus, do not appear to be a likely candidate to explain the increasing popularity of the affiliate structure before the Glass-Steagall Act.

A final regulatory difference across states that could have an impact on whether to open an affiliate concerns liability. The shareholders of all national banks and most state banks were subject to "double liability," that is, shareholders could be assessed an additional sum up to the paid-in capital of the bank if the bank were to fail (see Macey and Miller 1992b for more details). Since affiliates are standard "single" liability corporations, they may be used as a means to avoid the double liability

17 National City Bank's affiliate had by far the largest number of offices of any affiliate, with roughly 60 around the country. 
obligation. ${ }^{18}$ If affiliates were formed for this purpose, then they should be more frequent in states with double liability than states with standard single liability for bank shareholders. We found no statistically or economically significant difference in the usage of affiliates by state banks between the states with different liability obligations for bank shareholders. ${ }^{19}$

\section{Ex Ante Differences between Departments and Affiliates}

Our discussion thus far suggests that regulations, or changes in regulations, do not appear to have caused banks to move towards underwriting through affiliates during the 1920s. An alternative explanation is that banks voluntarily chose, after trading off the costs and benefits, to underwrite through affiliates rather than through departments. We now investigate possible costs of the department structure relative to affiliates. In principle, we would like to compare a variety of measures, including (a) underwriting costs, (b) the extent to which securities are widely placed, (c) the kinds of securities and firms underwritten, (d) the prices obtained for securities, and (e) the post-issue performance of the securities. Unfortunately, consistent and reliable data do not exist for the first two measures even today and certainly not in the 1920 s. The last three measures, however, should permit us to address what is usually considered to be the primary function of underwriters: to investigate the quality of proposed issues and then to certify them to the market (see, for example, Beatty and Ritter 1986 and Smith 1986). The types of securities underwritten by the different structures is suggestive of their comparative advantage in performing this function. Similarly, differences in prices obtained for otherwise equivalent securities underwritten by the two structures provides direct evidence of their relative effectiveness in certifying the value of the securities to the market. We examine ex post performance in section IV.

\footnotetext{
18 Neither we nor Macey and Miller (1992b) were able to discover any court cases concerning the failure of an affiliate in which the liability issue arose so it is unclear how the rules worked in practice.

19 The absence in the contemporary literature of any discussion of taxes as a rationale for the choice of organizational form suggests this was not important.
} 


\subsection{Data}

We use American Underwriting Houses and Their Issues (1928 and 1930) to determine the types of activities each house undertook. This source groups all new public securities issues between January 1, 1.925 and December 31,1929 by underwriter. The listings include common and preferred stock and short and long bonds of private corporations and governments. The entry for each security lists the month of issue, issue size, the coupon, the price, maturity, and the underwriter(s). ${ }^{20}$ The monthly new capital flotations section of the CEC reports the implied yield to maturity for bonds. ${ }^{21}$ To adjust the yield for changes in discount rates over time, we subtract the long term government bond yield as reported in Banking and Monetary Statistics (1976) from the initial yields. As noted above, we include in our sample only those securities in which the commercial bank, trust, or its securities affiliate is the lead underwriter or syndicate manager. The Moody's manuals then provide ratings, debt, assets, industry, and other firm characteristics. We have a total of 906 securities underwritten by the two organizational forms.

\subsection{The Underwriting Activities of Departments and Affiliates}

Panel A of Table 4 compares the types of securities issued by the two organizational structures in our sample. The chi-squared test rejects the null hypothesis that the distribution of types of securities underwritten is the same for both houses. The separate affiliates tend to do more junior securities such as common and preferred stock while the departments tend to focus more on bonds. ${ }^{2}$

\footnotetext{
${ }^{20}$ Any ambiguities or missing information is resolved by examining the monthly reports in the Commercial and Financial Chronicle.

${ }^{21}$ We checked that the prices (associated with the implied yields) reported in the CFC and American Underwriting Houses do correspond to the trading prices soon after the issue. When the CFC did not report the implied yield to maturity for an issue, we calculate the yields from the data in American Underwriting Houses. Our results do not change if we drop observations for which we calculated the yields.

2 We also can consider the column percentages rather than row percentages in Table 4A. The market share of in each type of security for the internal department increases monotonically with the seniority and safety of the security. The department share is highest for short bonds (48 percent), lower for long bonds (38 percent) and preferred (26 percent), and least for equity (19 percent).
} 
Panel B of Table 4 compares the different types of issuers for which the departments and the affiliates underwrote. Internal departments focused a majority of their activity (63 percent) on industrial firms, whereas about 35 percent of securities underwritten by affiliates were for industrial companies. By contrast, public utility issues constitute a larger fraction of affiliates' activities ( 33 percent) than for the departments (18 percent).

There are a number of other potentially illuminating differences in issuer type across the organizational structures, but the numbers are sufficiently small that one must be cautious in drawing strong conclusions. Investment trusts, which tended to be more speculative, are a larger part of the affiliates' operations. Affiliates also tended to underwrite relatively more for foreign issuers, which may have been more costly for domestic owners to monitor than domestic issues. Overall, the main difference that results from Table 4 is that the departments tend to focus the on senior and less information-intensive securities, such as bonds. ${ }^{2}$

\subsection{The Relative Pricing of Bonds Underwritten by Departments and Affiliates}

We define the initial net yield as implied yield to maturity at the offering date minus the longterm government bond yield in the month of issue. The mean and median initial net yields for the affiliates are roughly 31 and 45 basis points lower than for the departments and the differences are statistically significant at the one percent level. ${ }^{24}$ We must, however, correct for differences in the quality of issues underwritten by the two organizational structures before drawing conclusions.

In Table 5, we attempt to make such adjustments by regressing the initial net yield on a variety of ex ante observable proxies for creditworthiness and an indicator variable for the organizational

\footnotetext{
2 We will examine differences in the characteristics of the issuers through the two structures in greater detail in section IV.

${ }^{24}$ The numbers in the text are for the sample of issuers for which we have balance sheet data, that is, for the sample included in the regressions. For the whole sample of long-term bonds, the mean (median) initial net yield for affiliates is 2.08 (2.06) and for internal departments is $2.43(2.56)$, and the differences are again statistically significant at the one percent level.
} 
structure of the underwriter. Larger and older firms, on average, tend to be of better credit quality than smaller and younger firms (see, for example, Petersen and Rajan 1994). As proxies for these factors, we include the $\log$ of the asset size (in thousands of dollars) of the firm being underwritten and the $\log$ of one plus the firm age in years. We also include the firm's debt-to-assets ratio before the bond issue. Finally, we include (but do not report the coefficient estimates for) indicators for the year of issue to proxy for differences in macro-economic conditions at the time of the issue, indicators for one-digit SIC codes to proxy for inter-industry differences in risk and debt capacity, and separate indicators for railroads and utilities.

As column (i) of Table 5 reveals, the firm size and firm age proxies are strongly negatively correlated with initial net yield. The higher is firm leverage before the issue, the higher is the yield on the bond. The department indicator is positive and economically and statistically significant $(\beta=0.13$, $t=2.3$ ). Department underwritten securities tend to have a yield which is 13 basis points (a basis point is one hundredth of a percentage point) more than an affiliate underwritten security. By comparison, a bond rated " $\mathrm{A}$ " by Moody's has a 14 basis point higher yield than a bond rated "Aa." The discount thus is approximately equivalent to one rating tick, which is economically significant. The result suggests that the public discounted the prices of department underwritten securities. ${ }^{25}$

To investigate the robustness of the results concerning the department indicator, we now examine a number of other factors that could affect our interpretation. The department indicator may be a proxy for omitted characteristics of the bank and its clients. We noted above that larger banks were more likely to set up affiliates. Larger banks, perhaps, are more likely to have large, established client firms who

\footnotetext{
${ }^{25}$ We also included explanatory variables such as whether a security is listed on an exchange, and the size of the issue, but these did not affect the coefficient estimates and are not reported. White's heteroscedasticity corrections were also applied to all the regressions reported. The internal department coefficient continued to be statistically significant. One might also be concerned that since multiple issues are underwritten by the same house, a random effects estimate may be more appropriate. We estimate a random effects model and find the coefficient of the department indicator to be slightly higher at 0.16, with higher standard errors. A Hausman specification test suggests the random effects and regressors are uncorrelated, so the model is not appropriate.
} 
they can bring to market. The department indicator could be an inverse proxy for bank size and, thus, for the quality of firms being brought to market. To control for this possibility, we include the $\log$ of bank assets in the regression. Beatty and Ritter (1986) emphasize the link between underwriter reputation and the quality of issues brought to the market. We include the (log of the) age of the bank as a proxy for the bank's reputation, and hence, of the quality of issues underwritten. The bank size variable also may proxy for a bank's reputation. Finally, nationally-chartered banks were supervised by different regulators and may have had different controls on their activities than the state chartered banks. To adjust for regulatory differences, we include an indicator variable which is one if the bank has a national charter and zero otherwise.

The estimates, after controlling for bank characteristics, are reported in column (ii). The department coefficient remains positive and statistically significant $(\beta=0.18, t=2.8)$. Larger and older banks thus tend either to bring better securities to the market or to certify them better. The coefficients on bank size and bank age are negative, although only bank age is marginally statistically significant. Interestingly, the securities underwritten by national banks tend to have higher initial net yields. ${ }^{20}$

Locational differences are another set of bank characteristics to take into account. In our sample, 63 percent of the banks with affiliates were located either in New York or in cities that could be considered financial centers. ${ }^{27}$ By contrast, only 44 percent of the banks underwriting through departments were in New York or other the financial centers. To adjust for this, we include indicators for whether the parent bank is in New York or other major financial centers. In addition, branching restrictions may have prevented banks from being "close" to clients, thereby making it more difficult for

\footnotetext{
${ }^{26}$ The results we obtain below are similar when we use the log of bank capital as a measure of bank size. As another measure of bank quality, we include the bank's capital-to-assets ratio, but this variable has no additional explanatory effect. We also estimate separate regressions for the sample of state chartered banks and national banks and find that the internal securities department coefficient is statistically significant in both.

${ }^{27}$ These include Boston, Chicago, Philadelphia, St. Louis, San Francisco, and Los Angeles.
} 
them to gather information about them (e.g., Dhawan 1994). The argument implies that banks in states that did not allow branching obtained lower prices for issues. ${ }^{20}$ To test this, we include indicators for whether the state in which the bank is headquartered permits only limited branching or has no branching restrictions.

After controlling for the locational factors in column (iii), the coefficient on the department indicator is still significant $(\beta=0.16, t=2.3)$. Interestingly, the higher initial net yield on bonds underwritten by banks in New York city suggests that these banks may have been perceived by the public as being more aggressive. That the Pecora committee hearings of 1933-1934 singled out a few New York banks for intense investigation supports this interpretation. ${ }^{29}$ Being located in other financial centers had a small, negative, and statistically insignificant effect on initial net yields. We do not find that restrictions on branching prevented banks from realizing higher prices. While bonds underwritten in limited branching states paid a statistically insignificant 8 basis points less than bonds underwritten in states disallowing branching, bonds in states with full branching paid a statistically significant 30 basis points more.

Adjusting for observable characteristics of the firm and underwriter, the first three columns of Table 5 suggest that department underwritten issues received lower prices (or had higher yields) relative to comparable affiliate underwritten issues. Other relevant information may have been available to the public at that time, so the list of factors we have included may not be complete. To attempt to take account of quality factors known at the time but that we may have omitted, we include the initial rating by the Moody's rating agency. We create five indicator variables for the top five ratings categories (Aaa,

\footnotetext{
23 To the extent that there is more noise in the underwriter's information, the public has a more dispersed distribution of a firm's quality, which leads it to attribute lower prices for fixed claim securities such as debt.

29 Ang and Richardson (1994) find that bonds underwritten by Chase and National City Company (which bore the brunt of the Pecora Committee investigations) offered higher yields than other comparable bonds, suggesting that these may have indeed been perceived as "rogue" banks.
} 
$\mathrm{Aa}, \mathrm{A}, \mathrm{Baa}$, and $\mathrm{Ba}$ ) which are one if the bond has that rating and zero otherwise, and the unrated bonds are the omitted category. ${ }^{30}$ If the department indicator is merely a proxy for omitted variables that were known to the public investor at that time of issue, the inclusion of the rating indicators should dramatically reduce the coefficient estimate and increase the standard error for the department indicator. Column (iv) of Table 5, however, demonstrates that this does not occur. The coefficient estimate drops only slightly to 0.14 and the t-statistic rises slightly. The main effect of the inclusion of the ratings indicators is to reduce the magnitude and statistical significance of the firm characteristics and to increase the adjusted $\mathrm{R}^{2}$ (from 0.39 to 0.52 ), suggesting that there is considerable information in the ratings. ${ }^{31}$ These results suggest that the higher demanded yield is related to the department structure and not to any omitted variable. ${ }^{32}$

\section{A Rational Discounting Explanation and some Supportive Contemporary Evidence}

The evidence from the previous sections indicate that the affiliate structure gained market share over the 1920s, regulation does not appear to explain the movement, departments tended to do more senior and safer securities, and the prices departments obtained for the securities they underwrote was lower than prices obtained by the affiliates, ceteris paribus. While the last fact suggests an explanation for the first, it simply replaces one puzzle with another; why were department underwriting subject to discounts by the public?

\footnotetext{
${ }^{30}$ More than two-thirds of the bonds were rated. Roughly 1 percent of the bonds were rated below Ba at issue, so we do not include a separate indicator for them.

${ }^{31}$ It is not surprising that almost all of the coefficients estimates in the regression shrink in magnitude because the ratings also partly contain the information contained in the included variables. We also estimate the regression after dropping the unrated bonds. The coefficient for the department indicator is $0.15(t=2.23)$ suggesting that the department indicator is not a proxy for information not available for the unrated bonds.

32 Also, we include squares of the firm and bank specific variables to check if the department indicator picks up non-linearities in the explanatory variables. The coefficient estimate on the department indicator and its standard error again is virtually unchanged.
} 
To search for an explanation, we scoured the contemporary literature for discussions of the pros and cons of different bank organizational structures. An important concern for bank management was the possibility that the public would sense potential conflicts of interest when certain financial functions were too closely linked within the bank, and this would hurt the bank's ability to do business. Some banks and trusts explicitly argued that having an internal department which underwrote and distributed securities could compromise the "soundness, integrity, and conservatism" of their investment advice, and such institutions proudly advertised that they did not have such a department (Peach 1941, p. 72). In 1925, for example, the Farmers' Loan and Trust Company of New York announced in the Commercial and Financial Chronicle (May 2, 1925, p. 2228): ${ }^{33}$

Due to our policy and firm conviction that, as a trustee, we should never place ourselves in the position of a buyer and seller of securities at the same time, we have never had a bond department. Our whole security department is organized for the impartial study of securities for the benefit of our customers and not for the sale of bonds to the public.

In addition, a contemporary casebook on investment banking discussed how considerations of the potential for conflicts of interest affected the way a bank's investment counselling operations were structured (Biddle and Bates 1931, pp.67-80). The "Lakeshore Niagara Bank and Trust Company" had a separately capitalized and incorporated securities affiliate named the "Lakeshore Niagara Corporation." In 1928, the bank decided that it wished to enhance its internal "statistical department" to be able to provide more investment advice to its customers. Some of the bank's managers were concerned that even though "it was the theoretical function of the statistical department to render unbiased advice on investment problems...this was not always understood by customers..." The bank first considered creating a new "investment management department" within the bank. The bank's management rejected this option, however, because the department "might be injured by the imputation that it was conducted for the benefit of the securities corporation in so far as its advice was biased in favor of securities offered

${ }^{33}$ The Central Hanover Bank and Trust Company is another example (Peach 1941, p.72). 
by the Lakeshore Niagara Corporation" (Biddle and Bates 1931, p.69). Instead, the bank decided that the investment management operation would be "incorporated as a subsidiary of the Lakeshore Niagara Bank and Trust Company independent of control by the trust department or the investment subsidiary" (Biddle and Bates 1931, p.72). This example illustrates that "this question of a conflict of interest" had an important effect on how commercial bankers chose to structure their securities-related businesses (Biddle and Bates 1931, p.70). ${ }^{34}$

This is not to say that the bank did not see any virtues in providing security advice. Even though management worried whether "an investment counsel department known to be affiliated with a securities selling organization could attract enough business to cover its overhead when in competition with independent investment counsel ${ }^{n}$ it felt that the fee from the appropriately structured department would "partially cover the rapidly mounting overhead." This discussion suggests that the bank managers believed that there were scope economies in joint activities but that they had to be traded-off against perceptions conflicts of interest in determining organizational form.

We can formulate these considerations into a theory of "rational discounting" for potential conflicts of interest that arise in universal banking and draw out further testable implications of the theory. Close ties between a commercial bank and its underwriting operations can increase the public's perceptions of conflicts of interest in the bank, and impair the bank's certification function, in two ways. First, if a client firm's prospects deteriorate without the public realizing it, a commercial bank may attempt to persuade its underwriting operation to bring out a public issue on behalf of the firm,

\footnotetext{
${ }^{34}$ Underscoring the sensitivity to the conflicts of interest issue, the bank decided to include the following clause in the contract with clients of the investment management subsidiary: "I understand that my attomey [the investment management subsidiary] is an organization in or with which the Lakeshore Niagara Bank and Trust Company and the Lakeshore Niagara Corporation are interested and affiliated, and I agree, therefore, that my attorney, whenever considering it to be in my best interests, shall have entire freedom to invest in securities in which said bank and/or corporation are or is interested, to buy from, sell to, trade or otherwise deal with and utilize the services of said bank and corporation... all to the same extent as an attorney having no interest or affiliation with said organizations or members thereof having no benefit from such transactions might do and without accountability for any benefit received" (Biddle and Bates .1931, p.73).
} 
misrepresent the issue's quality to the investing public in order to sell it, and use the proceeds to repay earlier bank loans made to the firm. Second, if the market does not know the quality of the bank's clientele, the bank may attempt to continue funding their best clients through bank loans and take only the weaker firms to the market. The first argument emphasizes moral hazard (that is, the banks have an incentive to bail out of bad bank loans by refinancing these firms in the public market) while the second emphasizes adverse selection (that is, banks will "cherry pick" their best clients).

Rational investors who perceive the potential for these conflicts should react by imposing a discount (risk premium) on the price of securities underwritten to the extent of the uncertainty generated by the potential conflicts. ${ }^{35}$ The discussion above suggests that bank managers believed organizational structure could affect the public investor's concern about conflicts of interest. While we do not have the data to detail the precise mechanism(s) through which structure affected organizational credibility, we can outline plausible candidates. To the extent that there were officers and directors of the affiliate who were not also officers and directors of the parent bank, the bank would have to convince more people to follow a policy that would not be in the interest of the affiliate acting on its own. The ability to co-ordinate actions between lending and underwriting at the operational level also may have been much more limited with the affiliate relative to an internal department structure. ${ }^{36}$ The affiliate would have a separate existence, profit stream, and balance sheet to report so any cross-subsidy of the bank's activity would be more transparent with a separate affiliate than with an internal department. A separate affiliate thus may

${ }^{35}$ See Saunders (1985) and Benston (1990) for a broad discussion and Rajan (1992), Puri (1993) and Kanatas and $\mathrm{Qi} \mathrm{(1994)} \mathrm{for} \mathrm{a} \mathrm{formal} \mathrm{analysis} \mathrm{of} \mathrm{these} \mathrm{issues.} \mathrm{Conflicts} \mathrm{of} \mathrm{interest} \mathrm{reduce} \mathrm{the} \mathrm{credibility} \mathrm{of} \mathrm{an} \mathrm{underwriter's}$ certification, thus adding noise to the quality signal received by the public. This would lead them to demand a higher yield for fixed income securities.

${ }^{36}$ In the affiliate structure, requests for non-routine co-operation (such as a bailout) would have to travel up from lending operations to the top management of the bank, to the top management of the affiliate and then down again to underwriting operations. In the department structure, such co-ordination could be achieved at a department head level reducing the organizational layers through which the communication and agreement had to take place (see Rotemberg 1995 for a detailed theory). 
have a stronger reason to compete for the bank's best clients and underwrite their public issues. Furthermore, faced with such "internal" competition, lending officers might be less willing to pass information about the quality of their client firms to the affiliate, thereby reducing the extent of "cherry picking."

Thus the public's perception that the potential for conflicts of interest was higher in departments may have lead a discount being rationally imposed. In the next section we investigate further implications of the rational discounting hypothesis. ${ }^{37}$

\section{Robustness Checks and Additional Implications of Rational Discounting}

\section{4,1. Differences in Size}

We noted earlier that there are important differences in size between banks underwriting through departments and banks underwriting through affiliates. On average, smaller banks and banks bringing fewer issues to market tend to underwrite through departments. Banks underwriting through affiliates had assets averaging \$316 million and underwrote an average of 18 issues over the 1925 to 1929 period. By contrast, banks underwriting through departments had assets averaging $\$ 119$ million and underwrote an average of 8 issues (the difference in number of issues is obviously related to the diminishing business of existing departments in the late 1920s). The size of operations is a potential determinant of whether

\footnotetext{
${ }^{37}$ One cannot always conclude that a difference in prices of similar securities obtained by different types of underwriters implies a difference in underwriting ability. Puri (1995) finds that securities underwritten by universal banks obtained higher prices than securities underwritten by investment banks and concludes that universal banks are better at underwriting. Unfortunately, there are plausible explanations of this finding that do not imply any difference in underwriting ability. Firms underwritten by aniversal bank are likely to have an ongoing lending relationship with it. While the relationship may provide better information to the bank's underwriting arm (the potential source of the universal bank's superiority in underwriting), by virtue of the lending relationship the bank may also be better able to control future agency and asymmetric information problems at the firm. This will enable the bank to insure the firm against possible future credit rationing (see Diamond 1991 for the theory and Petersen and Rajan 1994 for evidence). Both the ex ante information the lending relationship provides the underwriting arm and the ex post insurance it provides the firm against rationing would suggest higher prices for securities issued by firms with banking relationships. Universal banks may be no better at underwriting but may, on average, obtain higher prices for issues because the public prices the banking relationship in. By contrast, our paper examines underwriters who are equally likely to have banking relationships with the firms they underwrite.
} 
a bank adopts the affiliate form.

On the one hand, this difference may provide a partial explanation for why some banks continued to underwrite through departments despite being subject to a discount by the market. The larger banks who underwrote many issues may have found the fixed costs of switching to the affiliate form compensated by the reduction in discounts on the issues. The switching banks did have, on average, 60 percent more assets than banks that continued underwriting through departments. On the other hand, scale by itself does not explain what advantage the affiliate structure had over the department structure. The eight banks that switched from the department to the affiliate structure did not perceptibly increase the size of the issues they underwrote nor their annual number of issues underwritten.

The differences in scale of securities operations raises the question, however, of whether the inclusion of bank size is an adequate control. There are various, more direct measures of scale of underwriting one could use, such as the maximum or median size of issue underwritten by the securities arm in the period 1925 to 1929 or the capital dedicated to it. While the last measure is not available for departments, the first two are. Since both produce similar results, we report results only on the maximum size of issue underwritten as a measure of the scale of securities operations.

The maximum size of an issue underwritten through an internal department is $\$ 60$ million. There are four affiliates which underwrite issues larger than this. We include an indicator variable for issues underwritten by the four affiliates. After controlling for the scale of securities operations in this way, Column (i) of Table 6 column shows that the department indicator remains economically and statistically significant $(\beta=0.2, \mathrm{t}=2.5)$. $^{38}$

Large underwriters typically tap the market more often and have better reputations (or at least

38 Although we do not have the amount of capital dedicated to securities operations for departments, we have the total bank capital. Under the assumption that bank capital is correlated with capital dedicated to securities operations, we use bank capital to determine the cut-off. The results are unchanged if we include an indicator for the issues underwritten by the largest affiliates using this measure of size. 
there is less uncertainty about their quality). An implication of rational discounting is that the public will be more concerned about securities underwritten by small, and typically less reputable, departments than securities underwritten by large departments. Discounts thus should be larger for issues underwritten by small departments. A more subtle implication is that even measured relative to issues by affiliates of similar size, the discounts for small department issues should be larger.

The data is consistent with these predictions. We classify the underwriters as "small" (maximum size of issue underwritten is less than $\$ 2.5$ million) and "large" (maximum size of issue underwritten is between $\$ 2.5$ million and $\$ 60$ million). The four affiliates with maximum size of issue over $\$ 60$ million are classified as "extra-large." ${ }^{39}$ When we include separate indicators for small and large departments (Table 6, column (ii)), the coefficient on the small department indicator is statistically and economically larger $(\beta=0.27, t=3.25)$ than the coefficient on the large department indicator $(\beta=0.10, t=1.58)$. In the next column of Table 6, we also include indicator variables for small and large underwriters, regardless of structure. The estimates in column (iii) of Table 6 show that relative to issues underwritten by small affiliates, issues underwritten by small departments yield 28 basis points more $(t=1.95)$ while relative to issues underwritten by large affiliates, issues underwritten by large departments yield 14 basis points more $(t=1.68)$. By contrast, the size of the underwriter by itself has little effect. Small underwriter issues yield a statistically insignificant 3 basis points less, while large underwriter issues yield an insignificant 6 basis point less, than issues underwritten by the extra-large affiliates.

\subsection{The Mix of Securities and Clients Underwritten}

Rational discounting will affect the kinds of securities departments can bring to market. Similar to Myers and Majluf's (1984) argument, if investors are wary of the motives of an underwriter, in equilibrium the underwriter will be forced to issue securities that are less subject to information

\footnotetext{
${ }^{39}$ As noted above, no bond departments underwrote issues greater than $\$ 60$ million. After dropping the affiliates that underwrote issues greater than $\$ 60$ million in size, the median underwriter underwrote issues smaller than $\$ 2.5$ million. This accounts for the ranges we pick.
} 
asymmetries, i.e., bonds rather than stock, and more mature (hence less risky), larger, and less-indebted firms. The differential discount to which small and large departments are subject to suggests another subtle test of the discounting hypothesis. Relative to comparable affiliates, small departments should be more conservative in their choice of securities and clients than would be large departments. This is indeed the case..$^{00}$

In Table 7, we compare observable measures of creditworthiness for firms underwritten by different size categories of departments and affiliates. For the small underwriters, the firms brought to market by departments are slightly larger, older, and significantly less indebted. If we associate a number with a security's Moody's rating ( $\mathrm{Aaa}=1, \mathrm{Aa}=2, \ldots$ Unrated $=8$ ), internal departments underwrite securities that have a significantly higher rating. This result could be due, in part, to our observation that internal departments underwrite less equity which is junior, and hence low rated, than do the affiliates (10 percent versus 45 percent). Even when we restrict the sample only to long bonds, our finding that internal departments underwrite higher quality securities persists. Finally, 20 percent of bonds underwritten by small departments are investment grade, while only 6 percent of bonds underwritten by the small affiliates are. In summary, small departments on average underwrite higher quality firms and more senior securities than small affiliates, although not all of these differences are statistically significant at conventional levels.

For large underwriters, the quality differences are less pronounced. Large departments tend to underwrite smaller firms and younger firms, but the differences are not statistically significant. This is offset by the fact that they underwrite statistically significantly less indebted firms and statistically significantly better rated securities. The rating differences vanish when we correct for the fact that

\footnotetext{
- One could argue that for small underwriters, a two stage regression is more appropriate to explain the net yield, where the first stage corrects for the selection bias in securities brought to market. Unfortunately, there is no obvious instrument to identify the first stage. As we argue shortly, however, accounting for the selection bias would simply strengthen our results.
} 
departments underwrite much less equity (13 percent versus 28 percent); however, 44 percent of the bonds issued by large departments are investment grade, as compared to 39 percent for the large affiliates. Consistent with rational discounting, the small departments appear to underwrite relatively higher quality securities (based on observable factors) than small affiliates, while the large departments underwrite securities more similar in quality to those underwritten by large affiliates.

That small departments underwrite observationally safer firms and securities (Table 7) but are subject to higher discounts than comparable affiliates (Table 6, columns ii and iii) clearly supports the rational discounting theory. Furthermore, unless one makes the argument that the department indicator is correlated with an omitted quality variable which was (a) observable to the public at that time and (b) negatively correlated with the observable measures of quality, it appears unlikely that our results stem simply from omitted variables.

\subsection{Stated Purpose of the Issue}

When a new security is issued, the Commercial and Financial Chronicle provides a very brief indication about how the proceeds of the issue are to be used. The "stated purpose" of a number of issues was to repay debt. ${ }^{41}$ While one could expect the underwriter to disguise the purpose of the issue if the public viewed debt repayment as particularly suspicious, it may not always have been possible to do so. The rational discounting hypothesis would suggest that departments would suffer greater discounts when underwriting issues whose stated purpose was debt repayment. In column (iv) of Table 6, we include indicators if the underwriter is a department and the stated purpose of the issue is debt repayment, if the underwriter is a department and the stated purpose of the issue is not debt repayment, and if the underwriter is an affiliate and the stated purpose is debt repayment. Department issues whose stated

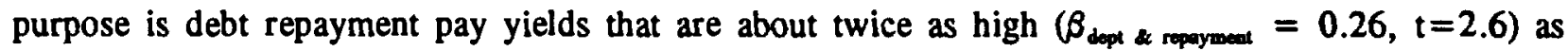

\footnotetext{
4l The stated purposes fell into the following categories: repay/refinance debt (and in a handful of cases bank loans were specified), acquisitions, capital and property improvement, "working capital," and "general corporate purposes."
} 
department issues whose purpose is not debt repayment $\left(\beta_{\text {depe }}\right.$ not naymeat $\left.=0.14, t=2.1\right)$ and affiliate issues whose purpose is debt repayment $\left(\beta_{\text {af \& naymot }}=0.13, t=1.15\right)$. The magnitude of the coefficients suggests that department issues were suspect regardless of the stated purpose (which is consistent both with the "cherry picking" interpretation of conflicts of interest and with the possibility that the public believed the purpose of the issue was often disguised), but that issues whose purpose was repayment were especially suspect if underwritten by departments. ${ }^{42}$ Affiliates, however, were less suspect, even when the purpose was debt repayment.

\subsection{More Continuous Measures of Independence}

Rational discounting would imply that the public would apply a greater discount to issues underwritten by affiliates that are more closely tied to the bank. The only consistent measure of independence for which we have enough data is the degree of overlap of the bank and affiliate boards. To the extent that the affiliate has board members who are independent from the bank, it would be more difficult for the bank to impose its will on the affiliate, and the public's perception of conflicts of interest should be lower (for modern evidence on the role of independent board members, see for example, Lee, et al. 1992).

We use two definitions of the director overlap variable, in columns (v) and (vi) of Table 6. Since we do not have data on board composition for some of the affiliates, the number of observations in the regression drops to 305 . First, we define the extent of director overlap as the number of directors common to both affiliate and parent bank divided by the number of directors of the affiliate. This overlap variable is set to zero for internal departments in the first definition. In the regression, we include this variable and the department indicator, thereby preserving a strict distinction between the department and affiliate. In the second definition, the overlap variable is once again the proportion of the directors of the affiliate who also are directors of the parent bank, but now the variable is set to one (100 percent

\footnotetext{
22 These coefficients are different only at the 16 percent confidence level.
} 
overlap) for the internal departments. The second definition considers the difference between the department and affiliates to be continuous along this dimension.

The estimation results for the first definition of overlap are in columns (v) of Table 6. The coefficients for both the department indicator and the affiliate director overlap variables are positive and of similar magnitudes to our previous results $\left(\beta_{\text {deparment }}=0.19, t=1.71, \beta_{\text {overlap }}=0.22, t=1.60\right)$. These point estimates imply that issues underwritten by an affiliate which has a board 100 percent controlled by the bank (so affiliate overlap equals 1) are discounted approximately to the same extent as issues underwritten by an internal department. The final column of Table 6 uses the second definition of overlap and again shows that greater overlap leads to a greater discount $\left(\beta_{\text {overap }}=0.20, t=1.84\right)$. These suggest that the degree of common managerial control is an important determinant of the extent to which an underwriter is viewed as subject to potential conflicts.

\subsection{The Ex Post Performance of the Underwritten Securities}

Since the securities underwritten by the departments appear to have been discounted relative to those underwritten by the affiliates, we now wish to investigate whether some ex ante discount was appropriate. One way to examine this issue is to compare the ex post performance of the underwritten securities. Unfortunately, little accurate pricing information is available on all but the very largest -- and typically highest rated -- issues so we cannot calculate returns on individual bonds (a data problem that also exists today). Instead, we measure performance by whether the bond defaults on either interest or principal. Following Dewing (1953, pp. 1175-82) voluntary extensions of a bond involving no interest or principle reduction are not considered defaults. Since most bonds in the 1925 to 1929 sample had maturities of 10 years or less and the severe economic downturns occur in 1930-1933 and 1937-1938, we follow the bonds until 1940 which should permit sufficient time to measure whether the firm fell into financial distress. The data sources on bond defaults are Moody's. Poor's. Fitch's Bond Book, The National Monthly Corporation Bond Summary, and the Fisher Manual of Valuable and Worthless 


\section{Securities.}

In our sample, the default rate is 31 percent for bonds underwritten by departments and 15 percent for bonds underwritten by affiliates, and the difference is statistically significant. Certainly, we must correct for other factors that might predict default. To do so, we estimate a logit regression where the dependent variable is "default" which equals one if the bond defaults by 1940 and zero otherwise (see Appendix II). We include indicators for industry, year of issue, and initial Moody's rating. In addition, we include proxies for quality of both the firm and the underwriter which we used in Table 5. In each specification, the indicator for bond department is positive and statistically significant. Even after adjusting for other quality indicators, the department issues tend to default more frequently than the affiliate issues, so some ex ante discount of the issues underwritten by the departments appears to have been reasonable. ${ }^{43}$

In summary, a number of predictions of the rational discounting hypothesis are borne out in the data. Investors appear to ask for higher promised yields for issues brought to market by underwriters who have a greater potential conflict of interest. Both the underwriter's ex ante choice of securities to issue, and the securities' ex post performance are consistent with the predictions of the discounting hypothesis.

\subsection{Other Explanations of the Move to the Affiliate Form}

We cannot rule out the possibility of other explanations for our results. Unfortunately, we do not have any data to compare the direct underwriting costs (such as syndicate fees, due diligence costs, etc.) of underwriting for departments and affiliates. Perhaps affiliates could bring firms to market at lower cost. In the absence of data on costs, we cannot refute this explanation for the evolution. On the other hand, perhaps there were economies of scope in information gathering and processing that some departments might have enjoyed relative to affiliates. This might explain why some banks continued to

\footnotetext{
43 Since we do not have retums data, we cannot determine whether the initial pricing was "efficient." Given our data, we can only conclude that the market appears to have gotten the sign right, not necessarily the magnitude.
} 
underwrite through departments, although it cannot account for the overall movement away from the department form and towards affiliates.

A more plausible explanation relates to change in the mix of securities issued during the 1920 s. Beginning in the latter half of 1928 and continuing through October of 1929, equity issuance grew rapidly in popularity, and firms switched from issuing bonds to issuing stocks. Since regulation, as noted above, created obstacles for national banks to underwrite equity through internal departments, the equity boom would have given national banks an incentive to move to the affiliate form. Most of the national banks, however, had already chosen the affiliate form long before the increase in equity issuance. The equity boom in 1929 thus does not appear to a major factor in their evolution toward affiliate form. As discussed above, state chartered banks do not seem to have been similarly restricted in their internal securities activities yet they moved to the affiliate form. The rational discounting hypothesis could provide an explanation for the state-chartered banks based on the growing popularity of equity. Since the discount the market imposes on department issues increases as the underwritten securities become more junior and information-sensitive, departments would have been at a disadvantage in underwriting equity. The equity boom starting in late 1928 may have accelerated the move towards the affiliate form, not because state banks were restricted from underwriting equity through departments, but because departments could not effectively underwrite equity.

Another possible explanation is bank risk aversion. Almost no banks were under the umbrella of deposit insurance in the late 1920s (see White 1983). As the quality of bond issuances deteriorated over the 1920s (see Kroszner and Rajan 1994), and as the issued securities became more junior, banks may have sought to protect themselves against shocks to the underwriting business (and potential bank runs) by distancing themselves from it. ${ }^{4}$ While this line of argument might account for some of the movement

\footnotetext{
4 A not unrelated argument is that it was harder for bank managers to control managers of affiliates. Consequently, affiliate managers were willing to take on greater risks without considering its impact on the rest of the bank's business.
} 
from the department towards the affiliate form, bank risk aversion does not explain the discount on department underwritten securities. Banks acting in a risk averse way would have had the incentive to underwrite the highest quality securities through departments, and a rational public should have priced these securities higher (i.e., required a lower yield) than comparable securities underwritten by the not-sochoosy affiliates. While other, partial, explanations of the movement towards the affiliate form over the 1920s may exist, the competitive disadvantage of departments stemming from the discounts imposed by a public concerned about the potential for conflicts of interest, we believe, is an integral part of the complete explanation.

\section{Discussion and Conclusion}

This paper has identified two important facts about universal banking in the U.S. prior to the Glass-Steagall Act. First, during the 1920s, commercial banks moved to underwriting securities through the separate affiliate structure rather than through internal securities departments. Regulations do not seem adequate to explain this evolution. Second, after controlling for ex ante observable quality factors, issues underwritten by departments were subject to an ex ante price discount relative to issues underwritten by affiliates. We tie these two results together by hypothesizing that the department structure itself was responsible for the discount being imposed due to a perception that internal departments may have been more subject to potential conflicts of interest than separate affiliates. This concern would have weakened the ability of the departments to certify the quality of the securities they were underwriting, thereby placing them at a competitive disadvantage relative to separate affiliates. The evolution towards the affiliate form could then be interpreted as the commercial banks' adaptation to the market's concerns about credibility of the internal department structure.

We then support the rational discounting interpretation of the discount and the evolution in two ways. First, we provide evidence from contemporary sources that concerns about conflicts of interest 
were an important factor influencing how bank managers chose to structure their operations. Second, we explore further implications of the hypothesis. Consistent with rational discounting, departments underwrote informationally-less-sensitive and safer issues than did affiliates, particularly so for the smaller departments which presumably had less developed reputations. Securities underwritten by the smaller departments were subject to greater discounts than those underwritten by similarly sized affiliates and the larger departments. When the stated purpose of an issue was to repay debt, the issue was subject to a discount which was greater when the underwriter was a department. Ultimately, the bonds underwritten by the departments did have a higher default rate than the bonds underwritten by the affiliates. Taken together, the evidence suggests that rational discounting and the competitive pressures stemming from it can explain the movement towards the affiliate form. ${ }^{\text {s }}$

An important question which we have not been able to address directly concerns the exact mechanism by which one organizational form can be perceived as more credible to outsiders than another. We do find that greater board control of an affiliate by the parent bank is associated with a greater discount for the securities it issues. This evidence suggests that the degree of managerial control or independence may be part of the explanation. Research in this area is in its infancy so there may be other explanations which we have not captured.

Our study, however, is one of the first to provide systematic evidence that internal organizational structure may indeed influence a financial firm's credibility and effectiveness. This supports bank regulators' concern that organization structure may have significant consequences but not necessarily that structure must be mandated. Market forces may lead firms to adopt the appropriate structure. Provided

\footnotetext{
${ }^{4}$ More modern evidence exists suggesting that conflicts of interest are important. For instance, when a number of investment banks in the United States went public in the 1980s, those underwriting their own initial public offerings had to underprice them more than those going public through an impartial underwriter. Packer (1995) finds that when a Japanese underwriter brings to market a firm in which its venture capital affiliate has an interest, the issue tends to be more heavily underpriced than other issues. Gande, Puri, Saunders and Walter (1994) find that issues underwritten by U.S. commercial banks where the primary purpose is to pay off bank debt require a higher yield than otherwise similar issues.
} 
the financial markets are competitive and externalities (such as implicit or explicit deposit insurance) are small, banks may naturally evolve towards the desired structure. ${ }^{46}$ More research, however, is required to understand the precise ways in which organizational structure can lead to effective distancing of the two activities, and hence greater credibility, before firm policy conclusions can be drawn. ${ }^{47}$

* Recent anecdotal evidence that market forces may lead to separation is that Deutsche Bank moved its investment banking operations to its separately incorporated and capitalized Morgan Grenfell subsidiary in London. Until recently, the German securities market bad been dominated by "insiders, " primarily the relatively wellinformed banks, and few individuals directly purchased securities. In these circumstances, perceptions about the credibility of the underwriter would have had a less important role in determining structural choice.

${ }^{47}$ It should be noted that the data used here do not address the question of the merits of universal banking per se. This paper focusses on ex ante evidence comparing the two structural forms of commercial bank involvement in securities underwriting. To examine whether banks should be involved in investment banking at all would require comparisons of universal banks and specialized investment banks. Kroszner and Rajan (1994), for example, compares the ex post performance of securities underwritten by (all types of) commercial banks with those underwritten by investment banks before the Glass-Steagall Act and finds that the commercial-bank-underwritten securities performed better otherwise comparable securities underwritten by investment banks. This result debunks a popular rationale for the Glass-Steagall Act. The debate over the merits of universal banking continues internationally. Calomiris (1995) argues that universal banks in Germany were responsible for the faster rate of industrial growth in Germany in the late nineteenth century relative to the U.S.; however, Weinstein and Yosha (1994) claim that universal banks retarded the growth of firms in Japan. 


\section{References}

Alchian, Armen and Harold Demsetz, "Production, Information Costs, and Economic Organization, American Economic Review, 1972, 62, 777-795.

Ang, James S. and Terry Richardson, "The Underwriting Experience of Commercial Bank Affiliates Prior to the Glass Steagall Act: A Re-examination of Evidence for Passage of the Act," Journal of Banking and Finance, 1994, 18 (2), 351-395.

Beatty, Randolph and Jay Ritter, "Investment Banking, reputation, and the underpricing of Initial Public Offerings", Journal of Financial Economics, 1986, 15, 213-232.

Benston, George J., The Separation of Commercial and Investment Banking, Oxford: Oxford University Press, 1990.

Biddle, Clinton and George Bates, Investment Banking: A Casebook, New York: McGraw Hill, 1931.

Blair, Christine E., "Bank Powers and the Separation of Banking from Commerce: An Historical Perspective," FDIC Banking Review, Spring/Summer 1994, 28-38.

Calomiris, Charles W., "The Costs of Rejecting Universal Banking: American Finance in the German Mirror, 1870-1914," in Naomi Lamoreaux and Daniel Raff, eds., Coordination and Information, Chicago: University of Chicago Press, 1995.

Carosso, Vincent P., Investment Banking in America: A History, Cambridge: Harvard University Press, 1970.

Chandler, Alfred D., The Visible Hand: The Managerial Revolution in American Business, Cambridge, MA: Harvard University Press, 1977.

Coase, Ronald, "The Nature of the Firm", Economica, 1937, 4, 386-405.

Dale, Richard, International Banking Deregulation: The Great Banking Experiment, Cambridge, MA: Blackwell Publishers, 1993.

Dewing Arthur S., The Financial Policy of Corporations, 5th ed., 2 vols, New York: Ronald Press Company, 1953.

Dhawan, Juhi, "Was Universal Banking Prevented by Regulation? The US Experience prior to the GlassSteagall Act," Unpublished ms., Brown University, 1994.

Diamond, Douglas, " Financial Intermediation and Delegated Monitoring", Review of Economic Studies, $1984,393-414$.

Diamond, Douglas, "Monitoring and reputation: the choice between bank loans and directly placed debt," Journal of Political Economy, 1991, 99, 688-721.

Edwards, George W., "The Myth of the Security Affiliate," Journal of the American Statistical Association, June 1942, 37, 225-32. 
Edwards, Jeremy and Klaus Fischer, Banks. Finance, and Investment in Germany, Cambridge University Press: Cambridge, 1994.

Fama, Eugene and Michael Jensen, "Separation of Ownership and Control," Journal of Law and Economics, 1983a, 26, 301-26.

Fama, Eugene and Michael Jensen, "Agency Problems and Residual Claims," Journal of Law and Economics, 1983b, 26, 327-49.

Gande, Amar, Manju Puri, Anthony Saunders and Ingo Walter, "Bank Underwriting of Debt Securities: Modern Evidence," Unpublished ms., New York University, 1995.

Greene, William, Econometric Analysis, second edition, New York: Macmillan, 1993.

Greenspan, Alan, "Statement by Alan Greenspan, Chairman, Board of Governors of the Federal Reserve System, Before the Senate Committee on Banking, Housing, and Urban Affairs, December 1, 1987," Federal Reserve Bulletin, 1988.

James, Christopher, "Some evidence on the uniqueness of bank loans", Journal of Financial Economics, 1987, 19, 217-235.

James, Christopher and Peggy Wier, "Borrowing relationships, intermediation, and the cost of issuing public securities", Journal of Financial Economics, 1990, 28, 149-171.

Kanatas, G. and J. Qi, "Underwriting by commercial banks: Conflicts of Interest vs. Scope Economies", Mimeo, University of South Florida, 1994.

Kane, Edward, The S\&L Insurance Mess: How Did It Happen? Washington, DC: Urban Institute, 1989.

Kaufman, George and Larry Mote, "Glass-Steagall: Repeal by Regulatory and Judicial Reinterpretation," Banking Law Journal, September-October 1990, 388-421.

Kaufman, George and Larry Mote, "Commercial Bank Securities Activities: What Really Happened in 1902," Lournal of Money. Credit. and Banking, August 1992, 370-74.

Kroszner, Randall, "The Evolution of Universal Banking and Its Regulation in Twentieth Century America," forthcoming in Anthony Saunders and Ingo Walter, ed., Universal Banking.

Kroszner, Randall and Raghuram Rajan, "Is the Glass-Steagall Act Justified? A Study of the U.S. Experience with Universal Banking before 1933," American Economic Review, September 1994, 84, 810-32.

Kroszner, Randall and Philip Strahan, "Regulatory Incentives and the Thrift Crisis: Dividends, Mutual-toStock Conversions, and Financial Distress," Unpublished ms., University of Chicago, 1995.

Kroszner, Randall and Thomas Stratmann, "Competition among Political Pressure Groups and the Organization of Congress: Theory and Evidence from Financial Services Political Action Committees," Unpublished ms., University of Chicago, 1995.

Lang, Larry and Rene Stulz, "Tobin's q, Corporate Diversification, and Firm Performance," Lournal of 
Political Economy, 1994, 102, 1248-91.

Lee, Chun, Stuart Rosenstein, Rangan Nanda, and Wallace Davidson, "Board Composition and Shareholder Wealth: The case of management buyouts", Financial Management, Spring 1992, 58-72.

Leland, Hayne and David Pyle, "Informational Asymmetries, Financial Structure, and Financial Intermediation," Journal of Finance, June 1977, 32, 371-87.

Lummer, Scott and John McConnell, "Further Evidence on the Bank Lending Process and the Capital Market Response to Bank Loan Agreements, Joumal of Financial Economics, 1989, 25, 99-122.

Macey, Jonathan and Geoffrey Miller, Banking Law and Regulation, Boston: Little, Brown and Company, 1992a.

Macey, Jonathan and Geoffrey Miller, "Double Liability of Bank Shareholders: History and Implications," Wake Forest Law Review, 1992b, vol. 27, 31-62.

Mayers, David and Clifford Smith, "Ownership Structure and Control: Mutualization of Stock Life Insurance Companies," Journal of Financial Economics, 1986, 16, 73-99.

Mayers, David and Clifford Smith, "Ownership Structure Across Lines of Property-casualty Insurance," Journal of Law and Economics, 1988, 31, 351-78.

Milgrom, Paul and John Roberts, Economics. Organization and Management, Englewood Cliffs, NJ: Prentice Hall, 1992.

Moore, Terris, "Security Affiliate versus Private Investment Banker - A Study in Security Organizations," Harvard Business Review, July 1934, 12, 478-84.

Myers, Stewart and Nicholas Majluf, "Corporate Financing and Investment Decisions When Firms Have Information that Investors Do Not Have," Journal of Financial Economics, 13, 187-221.

O’Hara, Maureen, "Property Rights and the Financial Firm," Journal of Law and Economics, 1981, 24, 317-32.

Packer, Frank, "Venture Capital, Bank Shareholding, and the Certification of IPOs: Evidence from the O.T.C. market in Japan", Research Paper 9401, Federal Reserve Bank of New York, 1994.

Peach, W. Nelson, The Security Affiliates of National Banks, Baltimore: Johns Hopkins Press, 1941.

Petersen, Mitchell and Raghuram Rajan, "The Benefits of Lending Relationships: Evidence from Small Business Data", Journal of Finance, 1994, 49, 3-37.

Preston, H. H. and A. R. Findlay, "Investment Affiliates Thrive," American Bankers Association Journal, May 1930 (a), 22, 1027-28, 1075.

Preston, H. H. and A. R. Findlay, "Era Favors Investment Affiliates," American Bankers Association 
Journal, June 1930 (b), 22, 1153-54, $1191-9$.

Puri, M., "A theory of conflicts of interest, intermediation and the pricing of underwritten securities", 1993, Unpublished ms., New York University

Puri, Manju, "Commercial Banks in Investment Banking: Conflict of Interest or Certification Role?" Unpublished ms., New York University, 1995.

Putterman, Louis and Randall Kroszner, eds, The Economic Nature of the Firm: A Reader, 2nd edition, New York: Cambridge University Press, forthcoming.

Rajan, Raghuram, "A theory of the costs and benefits of universal banking", C.R.S.P. Working Paper No. 346, University of Chicago, 1992.

Rajan, Raghuram, "An enquiry into the economics of extending bank powers", Unpublished ms., University of Chicago, 1994.

Rotemberg, Julio, "Process Versus Function Based Hierarchies", Unpublished ms., M.I.T., 1995.

Rotemberg, Julio and Garth Saloner, "Benefits of Narrow Business Strategies", American Economic Review, 1994, 84, 1330-1349.

Saunders, Anthony, "Conflicts of Interest: An Economic View", in I. Walter ed. Derequlating Wall Street: Commercial Bank Penetration of the Corporate Securities Market (John Wiley and Sons, New York), 1985.

Smith, Clifford, "Investment Banking and the Capital Acquisition Process," Journal of Financial Economics, 1986, 15, 3-29.

White, Eugene, The Regulation and Reform of the American Banking System, Princeton: Princeton University Press, 1983.

White, Eugene, "Before the Glass-Steagall Act: An Analysis of the Investment Banking Activities of National Banks," Explorations in Economic History, 1986, 23, 33-55.

Williamson, Oliver, Markets and Hierarchies, New York: Free Press, 1975.

Williamson, Oliver, The Economic Institutions of Capitalism, New York: Free Press, 1985.

American Underwriting Houses and Their Issues, Vols I and II, New York: National Statistical Service, 1928 and 1930.

Banking and Monetary Statistics, Washington, DC: Board of Governors of the Federal Reserve System, 1976 [1943].

Bond Quotation Record, New York, various issues, 1925-1930.

Commercial and Financial Chronicle, New York, various issues, 1925-1940. 
Federal Reserve Bulletin, Washington, DC: Board of Governors of the Federal Reserve System, various issues.

Robert D. Fisher Manual of Valuable and Worthless Securities, Volumes I-X, New York, 1927-1941.

Fitch Bond Book, New York: Fitch Publishing Company, 1925-1929.

Moody's Manuals: Industrial. Public Utility. Government and Municipalities, and Banking and Financial, New York, various volumes, 1925-1941.

National Securities Dealers of North America, New York: Herbert D. Siebert Company, February 1929.

National Monthly Corporation Bond Summary, New York: National Quotation Bureau, various volumes, 1925-1941.

National Monthly Stock Summary, New York: National Quotation Bureau, various volumes, 1925-1941.

Poor's Industrial Section and Ratings Manuals, New York, 1925-1941.

U.S. Senate, Committee on Banking and Currency, 71st Congress, 3rd Session, Operation of the National and Federal Reserve Systems: Hearings on S.R. 71, Washington, DC: Government Printing Office, 1931.

U.S. Senate, Committee on Banking and Currency, 72nd Congress, 1st Session, Operation of the National and Federal Reserve Systems: Hearings on S.R, 4115, Washington, DC: Government Printing Office, 1932.

U.S. Senate, Committee on Banking and Currency, 72nd Congress, 2nd Session and 73rd Congress, 2nd Session, Stock Exchange Practices: Hearings on S.R. 84 and S.R.56 and S.R. 97, Washington, DC: Government Printing Office, 1933-1934. 
TABLE 1: Amounts in millions of dollars and market shares (percent) of originations of all bond issues by all types of underwriters, 1927 - 1929. Private investment banks are firms that underwrite securities but do not have a bank charter. The commercial banks and trusts are firms with either a state or national bank charter and underwrite securities either through separately incorporated and capitalized affiliates or through an in-house securities department.

\begin{tabular}{lccc}
\hline \hline & & & \\
& 1927 & 1928 & 1929 \\
Type of Underwriter & & & \\
\hline & & 2,924 & 1,586 \\
All Private Investment Banks & 4,567 & $(70.4 \%)$ & $(54.6 \%)$ \\
& $(77.9 \%)$ & 1,229 & 1,319 \\
$\begin{array}{l}\text { All Commercial Banks and Trusts, } \\
\text { both organizational forms }\end{array}$ & 1,296 & $(29.6 \%)$ & $(45.4 \%)$ \\
& $(22.1 \%)$ & & \\
\multicolumn{1}{l}{ Separate Affiliates } & 755 & 970 & 1,204 \\
& $(12.9 \%)$ & $(23.4 \%)$ & $(41.4 \%)$ \\
Internal Departments & 541 & 259 & 115 \\
& $(9.2 \%)$ & $(6.2 \%)$ & $(4.0 \%)$ \\
Total Amount of Bond Issues & & & 2,905 \\
\hline
\end{tabular}

Source: Mitchell testimony (US Senate 1931, p.299). 
TABLE 2A: Number of securities underwritten (and relative shares in percent) by separate affiliates and internal departments of all depository institutions, 1925-1929. The sample includes all securities for which a depository institution was the sole underwriter, lead underwriter, or syndicate manager.

\begin{tabular}{lccccc}
\hline \hline & 1925 & 1926 & 1927 & 1928 & 1929 \\
\hline Separate Affiliate & $78(51 \%)$ & $95(56 \%)$ & $126(64 \%)$ & $146(65 \%)$ & $135(82 \%)$ \\
Internal Department & $75(49 \%)$ & $75(44 \%)$ & $69(36 \%)$ & $78(35 \%)$ & $29(18 \%)$ \\
Total & $153(100 \%)$ & $170(100 \%)$ & $195(100 \%)$ & $224(100 \%)$ & $164(100 \%)$ \\
\hline \hline
\end{tabular}

Sources: Moody's Bank and Finance Manual and American Underwriting Houses and Their Issues, volumes I and II. 
TABLE 2B: Number of securities underwritten (and relative shares in percent) by separate affiliates and internal departments of depository institutions with national and state charters, 1925-1929. The sample includes all securities for which a depository institution was the sole underwriter, lead underwriter, or syndicate manager. State charter refers to depository institutions chartered under state banking laws. National charter refers to banks chartered under national banking laws.

\begin{tabular}{|c|c|c|c|c|c|}
\hline & 1925 & 1926 & 1927 & 1928 & 1929 \\
\hline \multicolumn{6}{|l|}{ State Charter } \\
\hline Separate Affiliate & $45(39 \%)$ & $40(38 \%)$ & $54(46 \%)$ & $61(47 \%)$ & $55(68 \%)$ \\
\hline Internal Department & $70(61 \%)$ & $66(62 \%)$ & $62(54 \%)$ & $70(53 \%)$ & $26(32 \%)$ \\
\hline Total & $115(100 \%)$ & $106(100 \%)$ & $116(100 \%)$ & $131(100 \%)$ & $81(100 \%)$ \\
\hline \multicolumn{6}{|l|}{ National Charter } \\
\hline Separate Affiliate & $33(87 \%)$ & $55(86 \%)$ & $72(91 \%)$ & $85(92 \%)$ & $80(96 \%)$ \\
\hline Internal Department & $5(13 \%)$ & $9(14 \%)$ & $7(9 \%)$ & $8(8 \%)$ & $3(4 \%)$ \\
\hline Total & $38(100 \%)$ & $64(100 \%)$ & $79(100 \%)$ & $93(100 \%)$ & $83(100 \%)$ \\
\hline
\end{tabular}

Sources: Moody's Bank and Finance Manual and American Underwriting Houses and Their Issues, volumes I and II. 
TABLE 3A: Distribution of affiliates and internal departments operating in states with different branching restrictions, 1925-1929. "Full branching" states have no restrictions on branching of depository institutions. "Limited branching" states have some restrictions on the location and/or number of branches. "Branching prohibited" states permit no branches.

\begin{tabular}{lcccc}
\hline \hline & $\begin{array}{c}\text { Branching } \\
\text { Prohibited }\end{array}$ & $\begin{array}{c}\text { Limited } \\
\text { Branching }\end{array}$ & $\begin{array}{c}\text { Full } \\
\text { Branching }\end{array}$ & Total \\
\hline & $14(42 \%)$ & $13(37 \%)$ & $5(71 \%)$ & $32(43 \%)$ \\
Separate Affiliate & $19(58 \%)$ & $22(63 \%)$ & $2(29 \%)$ & $43(57 \%)$ \\
Internal Department & $33(100 \%)$ & $35(100 \%)$ & $7(100 \%)$ & $75(100 \%)$ \\
Total & & & & \\
\hline
\end{tabular}

${ }^{a} \mathrm{Chi}^{2}$ is the Pearsons $\chi^{2}$ for the hypothesis that the internal department and separate affiliate rows are from the same distribution.

Sources: Federal Reserve Bulletin (1930), Moody's Bank and Finance Manual and American Underwriting Houses and Their Issues, volumes I and II. 
TABLE 3B: Distribution of affiliates and internal departments of state and nationally chartered depository institutions operating in states with different branching restrictions, 1925-1929. "Full branching" states have no restrictions on branching of depository institutions. "Limited branching" states have some restrictions on the location and/or number of branches. "Branching prohibited" states permit no branches. State charter refers to depository institutions chartered under state banking laws. National charter refers to banks chartered under national banking laws.

\begin{tabular}{llcccc}
\hline \hline & & $\begin{array}{c}\text { Branching } \\
\text { Prohibited }\end{array}$ & $\begin{array}{c}\text { Limited } \\
\text { Branching }\end{array}$ & $\begin{array}{c}\text { Full } \\
\text { Branching }\end{array}$ & Total \\
\hline State Charter & & & & & \\
& Separate Affiliate & $5(22 \%)$ & $4(20 \%)$ & $1(33 \%)$ & $10(22 \%)$ \\
& Internal Department & $18(78 \%)$ & $16(80 \%)$ & $2(67 \%)$ & $36(78 \%)$ \\
& Total & $23(100 \%)$ & $20(100 \%)$ & $3(100 \%)$ & $46(100 \%)$
\end{tabular}

$\mathrm{Chi}^{2}(2)=0.27^{\mathrm{a}}, \mathrm{p}=0.87$

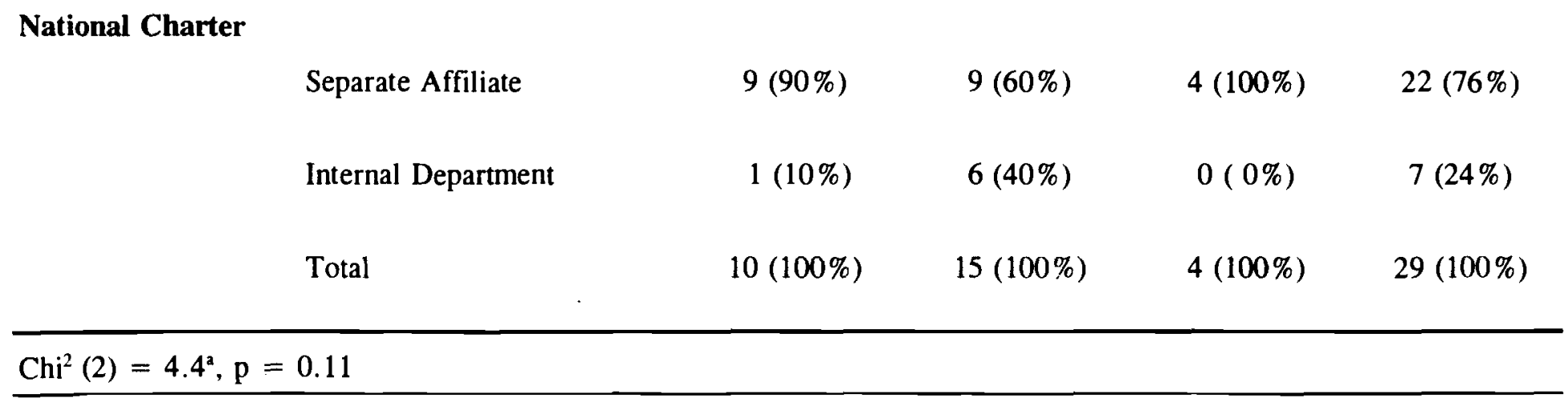

${ }^{a} \mathrm{Chi}^{2}$ is the Pearsons $\chi^{2}$ for the hypothesis that the internal department and separate affiliate rows are from the same distribution.

Sources: Federal Reserve Bulletin (1930), Moody's Bank and Finance Manual and American Underwriting Houses and Their Issues. 
TABLE 4: Number (percent) of securities issued by the sample of depository institutions through affiliates and internal securities departments between January 1925 and December 1929, by type of security and type of issuer. Separate affiliate refers to the separately incorporated and capitalized securities affiliate of a commercial bank or trust. Internal department refers to the in-house securities department of a commercial bank or trust.

Panel A: Types of Securities Issued

\begin{tabular}{lccccc}
\hline $\begin{array}{c}\text { Organization of } \\
\text { Securities Operation }\end{array}$ & $\begin{array}{c}\text { Common } \\
\text { Stock }\end{array}$ & $\begin{array}{c}\text { Preferred } \\
\text { Stock }\end{array}$ & $\begin{array}{c}\text { Short-term } \\
\text { Bonds }\end{array}$ & $\begin{array}{c}\text { Long-term } \\
\text { Bonds }\end{array}$ & Total \\
\hline Separate Affiliate & 44 & & & & \\
& $(7.6 \%)$ & $(14.3 \%)$ & $(6.9 \%)$ & $(71.2 \%)$ & $(100 \%)$ \\
Internal Department & 10 & 30 & 38 & 248 & 326 \\
& $(3.1 \%)$ & $(9.2 \%)$ & $(11.7 \%)$ & $(76.1 \%)$ & $(100 \%)$ \\
\hline $\mathrm{Chi}^{2}(3)=17.7^{2}, \mathrm{p}$-value $=0.001$ & & & & & \\
\hline
\end{tabular}

Panel B: Types of Securities Issuers

\begin{tabular}{cccccccc}
\hline & $\begin{array}{c}\text { Industrial } \\
\text { Enterprises }\end{array}$ & Railroads & $\begin{array}{c}\text { Public } \\
\text { Utilities }\end{array}$ & $\begin{array}{c}\text { Real Estate } \\
\text { (Mortgages) }\end{array}$ & $\begin{array}{c}\text { Investment } \\
\text { Trusts }\end{array}$ & $\begin{array}{c}\text { Foreign } \\
\text { Government }\end{array}$ & $\begin{array}{c}\text { Foreign } \\
\text { Corporation }\end{array}$ \\
\hline Separate Affiliate & 203 & 37 & 189 & 10 & & & \\
& $(35.0 \%)$ & $(6.4 \%)$ & $(32.6 \%)$ & $(1.7 \%)$ & $(6.0 \%)$ & $(9.3 \%)$ & $(9.0 \%)$ \\
Internal Department & 219 & 11 & 57 & 10 & 10 & 13 & 6 \\
& $(67.2 \%)$ & $(3.4 \%)$ & $(17.5 \%)$ & $(3.1 \%)$ & $(3.1 \%)$ & $(4.0 \%)$ & $(1.8 \%)$ \\
\hline
\end{tabular}

$\mathrm{Chi}^{2}(6)=97.4^{\mathrm{a}}, \mathrm{p}$-value $=0.000$

a $\mathrm{Chi}^{2}$ is the Pearsons $\chi^{2}$ for the hypothesis that the internal department and separate affiliate rows are from the same distribution. Source: Compiled from American Underwriting Houses and their Issues (volumes I and II). 
TABLE 5: OLS estimates of the determinants of initial net yields on bonds underwritten by the internal securities departments and separate affiliates of commercial banks, 1925-1929." (T-statistics are in parentheses.)

\begin{tabular}{|c|c|c|c|c|}
\hline Independent Variable & (i) & (ii) & (iii) & (iv) \\
\hline $\begin{array}{l}\text { Indicator is } 1 \text { if the } \\
\text { underwriter is internal } \\
\text { securities department }\end{array}$ & $\begin{array}{c}0.13 \\
(2.31)\end{array}$ & $\begin{array}{c}0.18 \\
(2.83)\end{array}$ & $\begin{array}{c}0.16 \\
(2.27)\end{array}$ & $\begin{array}{c}0.14 \\
(2.30)\end{array}$ \\
\hline $\begin{array}{l}\text { Log of firm } \\
\text { assets in } \$ 000\end{array}$ & $\begin{array}{l}-0.07 \\
(-4.27)\end{array}$ & $\begin{array}{l}-0.06 \\
(-3.37)\end{array}$ & $\begin{array}{c}-0.06 \\
(-3.27)\end{array}$ & $\begin{array}{l}-0.02 \\
(-1.38)\end{array}$ \\
\hline Log of firm age in years & $\begin{array}{l}-0.06 \\
(-3.31)\end{array}$ & $\begin{array}{l}-0.07 \\
(-3.70)\end{array}$ & $\begin{array}{c}-0.07 \\
(-3.81)\end{array}$ & $\begin{array}{c}-0.04 \\
(-2.37)\end{array}$ \\
\hline $\begin{array}{l}\text { Debt to assets ratio } \\
\text { before the issue }\end{array}$ & $\begin{array}{c}0.37 \\
(2.64)\end{array}$ & $\begin{array}{c}0.36 \\
(2.55)\end{array}$ & $\begin{array}{c}0.31 \\
(2.22)\end{array}$ & $\begin{array}{c}0.23 \\
(1.81)\end{array}$ \\
\hline $\begin{array}{l}\text { Maturity of bond in } \\
\text { years }\end{array}$ & $\begin{array}{l}-0.00 \\
(-1.54)\end{array}$ & $\begin{array}{c}-0.00 \\
(-1.31)\end{array}$ & $\begin{array}{l}-0.00 \\
(-1.27)\end{array}$ & $\begin{array}{l}-0.00 \\
(-1.36)\end{array}$ \\
\hline $\begin{array}{l}\text { Indicator is } 1 \text { if bank is a } \\
\text { national bank }\end{array}$ & - & $\begin{array}{c}0.17 \\
(2.80)\end{array}$ & $\begin{array}{c}0.12 \\
(1.70)\end{array}$ & $\begin{array}{c}0.11 \\
(1.74)\end{array}$ \\
\hline Log of bank age in years & - & $\begin{array}{c}-0.09 \\
(-1.68)\end{array}$ & $\begin{array}{l}-0.05 \\
(-1.00)\end{array}$ & $\begin{array}{l}-0.01 \\
(-1.03)\end{array}$ \\
\hline $\begin{array}{l}\text { Log of bank assets } \\
\text { in } \$ 000\end{array}$ & - & $\begin{array}{c}-0.00 \\
(-0.09)\end{array}$ & $\begin{array}{l}-0.04 \\
(-1.09)\end{array}$ & $\begin{array}{l}-0.03 \\
(-1.18)\end{array}$ \\
\hline $\begin{array}{l}\text { Indicator is } 1 \text { if bank is } \\
\text { in New York }\end{array}$ & - & - & $\begin{array}{c}0.19 \\
(1.77)\end{array}$ & $\begin{array}{c}0.19 \\
(2.03)\end{array}$ \\
\hline $\begin{array}{l}\text { Indicator is } 1 \text { if bank is } \\
\text { in other financial center }\end{array}$ & - & - & $\begin{array}{l}-0.07 \\
(-0.80)\end{array}$ & $\begin{array}{c}-0.04 \\
(-0.53)\end{array}$ \\
\hline $\begin{array}{l}\text { Indicator is } 1 \text { if state } \\
\text { allows limited branching }\end{array}$ & - & - & $\begin{array}{c}-0.08 \\
(-0.84)\end{array}$ & $\begin{array}{l}-0.05 \\
(-0.66)\end{array}$ \\
\hline $\begin{array}{l}\text { Indicator is } 1 \text { if state } \\
\text { allows unrestricted } \\
\text { branching }\end{array}$ & - & - & $\begin{array}{c}0.30 \\
(2.63)\end{array}$ & $\begin{array}{c}0.28 \\
(2.66)\end{array}$ \\
\hline $\begin{array}{l}\text { Includes indicators for } \\
\text { initial Moody's ratings } \\
\text { categories }^{b}\end{array}$ & No & No & No & Yes \\
\hline Number of Observations & 422 & 422 & 422 & 422 \\
\hline Adjusted $\mathbf{R}^{2}$ & 0.37 & 0.38 & 0.39 & 0.52 \\
\hline
\end{tabular}

a All specifications include indicators for (a) the year of issue, (b) one-digit SIC codes, (c) whether the issuer is a railroad, and (d) whether the issuer is a public utility. These coefficient estimates are not reported.

' Separate indicators are included for each Moody's rating category: that is, the first ratings indicator equals one if Moody's initially rated the bond Aaa and zero otherwise; the second ratings indicator equals one if the bond was rated $\mathrm{Aa}$, etc. 
Sources and Notes: Initial net yield is defined as the implied yield to maturity at the offering date reported in the Commercial and Financial Chronicle or American Underwriting Houses and their Issues minus the long-term government bond rate in the month of issue obtained from Banking and Monetary Statistics. The securities department indicator is one if the underwriter of the issue is an in-house securities department and zero if the underwriter is an affiliate. The total assets of the firm are book assets in the year before the issue as listed in Moody's. Firm age is the number of years that the firm has existed at the date of issue. The debt to total assets ratio is the ratio of total debt (including notes) to book assets in the year before the issue, as obtained from Moodys. The maturity of the bond is the average of maturities for a serial bond and the final maturity for a bond with a balloon payment in years. A national bank has a federal bank charter. Bank age is the number of years since the founding of the bank with which the affiliate or the securities department is associated. Bank assets is the total book value of assets of the bank. Other financial centers include Boston, Chicago, Philadelphia, St. Louis, San Francisco, and Los Angeles. Branching status is obtained from the Federal Reserve Bulletin (1930). Summary statistics for the variables are in the Appendix. 
TABLE 6: Alternative specifications for the OLS estimates of the determinants of initial net yields on bonds underwritten by the internal securities departments and separate affiliates of commercial banks, 1925-1929." (T-statistics are in parentheses. The table continues on the next page.)

\begin{tabular}{|c|c|c|c|c|c|c|}
\hline Independent Variable & (i) & (ii) & (iii) & (iv) & (v) & (vi) \\
\hline $\begin{array}{l}\text { Indicator is } 1 \text { if the } \\
\text { underwriter is internal } \\
\text { securities department }\end{array}$ & $\begin{array}{c}0.20 \\
(2.50)\end{array}$ & - & - & - & $\begin{array}{c}0.19 \\
(1.71)\end{array}$ & - \\
\hline $\begin{array}{l}\text { Indicator if largest issue } \\
\text { by underwriter is above } \\
\$ 60 \text { million }^{b}\end{array}$ & $\begin{array}{c}0.08 \\
(1.11)\end{array}$ & - & - & - & - & - \\
\hline $\begin{array}{l}\text { Indicator is } 1 \text { if } \\
\text { underwriter is "small" } \\
\text { internal department }\end{array}$ & - & $\begin{array}{c}0.27 \\
(3.25)\end{array}$ & $\begin{array}{c}0.28 \\
(1.95)\end{array}$ & - & - & - \\
\hline $\begin{array}{l}\text { Indicator is } 1 \text { if } \\
\text { underwriter is "large" } \\
\text { internal department }\end{array}$ & - & $\begin{array}{c}0.10 \\
(1.58)\end{array}$ & $\begin{array}{c}0.14 \\
(1.68)\end{array}$ & - & - & - \\
\hline $\begin{array}{l}\text { Indicator is } 1 \text { if } \\
\text { underwriter is "small" }\end{array}$ & - & - & $\begin{array}{c}-0.03 \\
(-0.25)\end{array}$ & - & - & - \\
\hline $\begin{array}{l}\text { Indicator is } 1 \text { if } \\
\text { underwriter is "large" }\end{array}$ & - & - & $\begin{array}{l}-0.06 \\
(-0.77)\end{array}$ & - & - & - \\
\hline $\begin{array}{l}\text { Indicator is } 1 \text { if internal } \\
\text { securities dept. and } \\
\text { stated purpose is to } \\
\text { refinance debt or loans }\end{array}$ & - & - & - & $\begin{array}{c}0.26 \\
(2.61)\end{array}$ & - & - \\
\hline $\begin{array}{l}\text { Indicator is } 1 \text { if internal } \\
\text { securities dept. and } \\
\text { refinancing of debt or } \\
\text { loans is not stated }\end{array}$ & - & - & - & $\begin{array}{c}0.14 \\
(2.14)\end{array}$ & - & - \\
\hline $\begin{array}{l}\text { Indicator is } 1 \text { if separate } \\
\text { affiliate and stated } \\
\text { purpose is to refinance } \\
\text { debt or loans }\end{array}$ & - & - & - & $\begin{array}{c}0.13 \\
(1.15)\end{array}$ & - & - \\
\hline $\begin{array}{l}\text { Director overlap between } \\
\text { parent bank and affiliate } \\
\text { with department set to } 0^{d}\end{array}$ & - & - & - & - & $\begin{array}{c}0.22 \\
(1.60)\end{array}$ & - \\
\hline $\begin{array}{l}\text { Director overlap between } \\
\text { parent bank and affiliate } \\
\text { with department set to } 1^{d}\end{array}$ & - & - & - & - & - & $\begin{array}{c}0.20 \\
(1.84)\end{array}$ \\
\hline $\begin{array}{l}\text { Log of firm } \\
\text { assets in } \$ 000\end{array}$ & $\begin{array}{l}-0.02 \\
(-1.15)\end{array}$ & $\begin{array}{c}-0.02 \\
(-0.95)\end{array}$ & $\begin{array}{l}-0.02 \\
(-1.04)\end{array}$ & $\begin{array}{c}-0.03 \\
(-1.47)\end{array}$ & $\begin{array}{l}-0.02 \\
(-0.72)\end{array}$ & $\begin{array}{l}-0.02 \\
(-0.76)\end{array}$ \\
\hline Log of firm age in years & $\begin{array}{l}-0.04 \\
(-2.25)\end{array}$ & $\begin{array}{c}-0.04 \\
(-2.20)\end{array}$ & $\begin{array}{l}-0.04 \\
(-2.14)\end{array}$ & $\begin{array}{c}-0.04 \\
(-2.52)\end{array}$ & $\begin{array}{c}-0.05 \\
(-2.28)\end{array}$ & $\begin{array}{l}-0.05 \\
(-2.30)\end{array}$ \\
\hline
\end{tabular}




\begin{tabular}{|c|c|c|c|c|c|c|}
\hline $\begin{array}{l}\text { Debt to assets ratio } \\
\text { before the issue }\end{array}$ & $\begin{array}{c}0.23 \\
(1.81)\end{array}$ & $\begin{array}{c}0.20 \\
(1.58)\end{array}$ & $\begin{array}{c}0.20 \\
(1.59)\end{array}$ & $\begin{array}{c}0.24 \\
(1.93)\end{array}$ & $\begin{array}{c}0.12 \\
(0.73)\end{array}$ & $\begin{array}{c}0.13 \\
(0.78)\end{array}$ \\
\hline $\begin{array}{l}\text { Maturity of bond in } \\
\text { years }\end{array}$ & $\begin{array}{l}-0.00 \\
(1.40)\end{array}$ & $\begin{array}{c}-0.00 \\
(-1.28)\end{array}$ & $\begin{array}{l}-0.00 \\
(-1.31)\end{array}$ & $\begin{array}{l}-0.00 \\
(-1.22)\end{array}$ & $\begin{array}{l}-0.00 \\
(-0.42)\end{array}$ & $\begin{array}{l}-0.00 \\
(-0.40)\end{array}$ \\
\hline $\begin{array}{l}\text { Indicator is } 1 \text { if bank is } \\
\text { a national bank }\end{array}$ & $\begin{array}{c}0.13 \\
(2.01)\end{array}$ & $\begin{array}{c}0.10 \\
(1.62)\end{array}$ & $\begin{array}{c}0.12 \\
(1.78)\end{array}$ & $\begin{array}{c}0.10 \\
(1.60)\end{array}$ & $\begin{array}{c}0.03 \\
(0.42)\end{array}$ & $\begin{array}{l}0.05 \\
(0.67)\end{array}$ \\
\hline Log of bank age in years & $\begin{array}{l}-0.01 \\
(-0.29)\end{array}$ & $\begin{array}{l}-0.01 \\
(-0.21)\end{array}$ & $\begin{array}{l}-0.01 \\
(-0.31)\end{array}$ & $\begin{array}{c}-0.00 \\
(-0.03)\end{array}$ & $\begin{array}{l}-0.01 \\
(-0.21)\end{array}$ & $\begin{array}{l}-0.01 \\
(-0.21)\end{array}$ \\
\hline $\begin{array}{l}\text { Log of bank assets } \\
\text { in } \$ 000\end{array}$ & $\begin{array}{c}-0.04 \\
(-1.24)\end{array}$ & $\begin{array}{l}-0.01 \\
(-0.40)\end{array}$ & $\begin{array}{l}-0.02 \\
(-0.48)\end{array}$ & $\begin{array}{c}-0.04 \\
(-1.23)\end{array}$ & $\begin{array}{c}-0.07 \\
(-1.79)\end{array}$ & $\begin{array}{l}-0.06 \\
(-1.91)\end{array}$ \\
\hline $\begin{array}{l}\text { Indicator is } 1 \text { if bank is } \\
\text { in New York }\end{array}$ & $\begin{array}{c}0.18 \\
(1.86)\end{array}$ & $\begin{array}{c}0.14 \\
(1.51)\end{array}$ & $\begin{array}{c}0.14 \\
(1.43)\end{array}$ & $\begin{array}{c}0.20 \\
(2.09)\end{array}$ & $\begin{array}{c}0.21 \\
(1.98)\end{array}$ & $\begin{array}{c}0.21 \\
(1.97)\end{array}$ \\
\hline $\begin{array}{l}\text { Indicator is } 1 \text { if bank is } \\
\text { in other financial center }\end{array}$ & $\begin{array}{l}-0.04 \\
(-0.46)\end{array}$ & $\begin{array}{l}-0.05 \\
(-0.68)\end{array}$ & $\begin{array}{l}-0.05 \\
(-0.59)\end{array}$ & $\begin{array}{l}-0.05 \\
(-0.62)\end{array}$ & $\begin{array}{c}-0.07 \\
(-0.65)\end{array}$ & $\begin{array}{c}0.06 \\
(0.59)\end{array}$ \\
\hline $\begin{array}{l}\text { Indicator is } 1 \text { if state } \\
\text { allows limited branching }\end{array}$ & $\begin{array}{c}-0.04 \\
(-0.49)\end{array}$ & $\begin{array}{l}-0.06 \\
(-0.72)\end{array}$ & $\begin{array}{l}-0.05 \\
(-0.57)\end{array}$ & $\begin{array}{l}-0.05 \\
(-0.65)\end{array}$ & $\begin{array}{c}-0.07 \\
(-0.69)\end{array}$ & $\begin{array}{c}0.59 \\
(0.63)\end{array}$ \\
\hline $\begin{array}{l}\text { Indicator is } 1 \text { if state } \\
\text { allows unrestricted } \\
\text { branching }\end{array}$ & $\begin{array}{c}0.30 \\
(2.84)\end{array}$ & $\begin{array}{c}0.27 \\
(2.66)\end{array}$ & $\begin{array}{c}0.30 \\
(2.73)\end{array}$ & $\begin{array}{c}0.28 \\
(2.69)\end{array}$ & $\begin{array}{l}0.56 \\
(2.87)\end{array}$ & $\begin{array}{c}0.55 \\
(2.87)\end{array}$ \\
\hline Number of Observations & 422 & 422 & 422 & 422 & 305 & 305 \\
\hline Adjusted $\mathbf{R}^{2}$ & 0.52 & 0.52 & 0.52 & 0.52 & 0.47 & 0.48 \\
\hline
\end{tabular}

all specifications include separate indicators for each Moody's rating category: that is, the first ratings indicator equals one if Moody's initially rated the bond Aaa and zero otherwise; the second ratings indicator equals one if the bond was rated $\mathrm{Aa}$, etc. All specifications also include indicators for (a) the year of issue, (b) one-digit SIC codes, (c) whether the issuer is a railroad, and (d) whether the issuer is a public utility. These coefficient estimates are not reported.

' No internal bond department underwrites a bond issue greater than $\$ 60$ million during our sample period.

'If an underwriter's largest issue between 1925 and 1929 is less than or equal to $\$ 2.5$ million, it is classified as "small." If an underwriter's largest issue lies between $\$ 2.5$ million and $\$ 60$ million, it is classified as "large." (The maximum issue size for an internal bond department in our sample is $\$ 60$ million.) Affiliates which underwrote an issue greater than $\$ 60$ million are classified as "extra-large." The $\$ 2.5$ million cut-off is chosen because it is the median of the maximum issue sizes after dropping the extra-large underwriters.

${ }^{d}$ Director overlap between the parent bank and affiliate is the proportion of the directors of affiliate who also are directors of the parent bank; in the first definition, the variable is set to zero for internal departments and, in the second definition, is set to one for the internal departments.

Sources and Notes: Initial net yield is defined as the implied yield to maturity at the offering date reported in the Commercial and Financial Chronicle or American Underwriting Houses and their Issues minus the long-term government bond rate in the month of issue obtained from Banking and Monetary Statistics. The department indicator is one if the underwriter of the issue is an in-house securities department and zero if the underwriter is an affiliate. Stated purpose of the issue is obtained from the Commercial and 
Financial Chronicle. The total assets of the firm are book assets in the year before the issue as listed in Moodys. Firm age is the number of years that the firm has existed at the date of issue. The debt to total assets ratio is the ratio of total debt (including notes) to book assets in the year before the issue, as obtained from Moodys. The maturity of the bond is the average of maturities for a serial bond and the final maturity for a bond with a balloon payment in years. A national bank has a federal bank charter. Bank age is the number of years since the founding of the bank with which the affiliate or the securities department is associated. Bank assets is the book value of total assets of the bank. Other financial centers include Boston, Chicago, Philadelphia, St. Louis, San Francisco, and Los Angeles. Branching status is obtained from the Federal Reserve Bulletin (1930). Summary statistics for the variables are in the Appendix. 
TABLE 7: Characteristics of firms underwritten by affiliates and internal departments of depository institutions, $1925-1929$.

If an underwriter's largest issue between 1925 and 1929 is less than or equal to $\$ 2.5$ million, it is classified as small. If the issue size lies between $\$ 2.5$ million and $\$ 60$ million, it is classified as large. Only affiliates have the maximum size of the issue greater than $\$ 60$ million. These are classified as extra-large. $\$ 2.5$ million is the median issue size for all underwriters that had a maximum issue size of less than or equal to $\$ 60$ million. The data for this table are obtained from various editions of Moodys. The age of the firm is the number of years between the last change in control or founding of the firm and the issue date. The size of the firm is the book value of assets. The debt to assets ratio is the ratio of total debt (including both notes and bonds) to assets. The rating for the issue is the Moodys rating in the year of the issue. If that is not available, the rating is obtained for the following year. If the security is unrated in both years, it is classified as unrated. Medians for ratings are obtained by converting letter ratings into a numerical scale where a security rating of Aaa is assigned the number 1, Aa assigned $2, \ldots$ and an unrated security is assigned the number $\mathbf{8}$. Bonds are rated investment grade if their rating is Baa and above. The numbers for each cell vary.

\begin{tabular}{|c|c|c|c|c|c|c|c|}
\hline \multicolumn{8}{|c|}{ Firm Characteristics (mean for group) } \\
\hline & $\begin{array}{l}\text { number } \\
\text { of issues }\end{array}$ & $\begin{array}{l}\text { age of } \\
\text { firm }\end{array}$ & $\begin{array}{l}\text { size of firm } \\
(\$ 000)\end{array}$ & $\begin{array}{l}\text { debt to assets } \\
\text { ratio (before } \\
\text { issue) }\end{array}$ & $\begin{array}{l}\text { rating of } \\
\text { securities } \\
\text { issued }\end{array}$ & $\begin{array}{l}\text { rating of } \\
\text { bonds } \\
\text { issued }\end{array}$ & $\begin{array}{l}\text { fraction of bonds } \\
\text { rated investment } \\
\text { grade }\end{array}$ \\
\hline \multicolumn{8}{|l|}{ Small Underwriters } \\
\hline Departments & 140 & 12.5 & 5896 & $0.15^{*}$ & $6.66^{* *}$ & 6.62 & $20 \%$ \\
\hline Affiliates & 44 & 7.8 & 5491 & $0.22 *$ & $7.32 *$ & 7.19 & $6 \%$ \\
\hline \multicolumn{8}{|l|}{ Large Underwriters } \\
\hline Departments & 186 & 15.3 & 66714 & $0.19^{* *}$ & $5.26^{*}$ & 5.38 & $44 \%$ \\
\hline Affiliates & 166 & 19.6 & 143780 & $0.27^{\cdots *}$ & $5.72^{*}$ & 5.39 & $39 \%$ \\
\hline Extra Large Affiliates & 370 & 14 & 125607 & 0.34 & 4.29 & 4.01 & $78 \%$ \\
\hline
\end{tabular}

* Difference in means between departments and affiliates statistically significant at the 10 percent level.

** Difference in means between departments and affiliates statistically significant at the 5 percent level.

*** Difference in means between departments and affiliates statistically significant at the 1 percent level. 
APPENDIX I: Summary statistics for variables used in the regressions. $(N=422)$

\section{Variable}

Initial net yield

Indicator is 1 if the underwriter is an internal securities department

Log of firm assets in $\$ 000$

Log of firm age in years

Debt to assets ratio before the issue

Maturity of bond in years

Indicator is 1 if bank is a national bank

Log of bank age in years

Log of bank assets in $\$ 000$

Indicator is 1 if bank is in New

York

Indicator is 1 if bank is in other

financial center

Indicator is 1 if state allows limited branching

Indicator is 1 if state allows unrestricted branching

Indicator 1 if underwriter is "small"

Indicator is 1 if underwriter is

"large"

Indicator is 1 if stated purpose of issue is to refinance debt or loans

Director overlap between bank and affiliate, set to 0 for departments

Director overlap between bank and affiliate, set to 1 for departments

\section{Mean}

2.11

0.39

9.98

2.22

0.26

17.53

0.32

3.83

12.12

0.31

0.47

0.47

0.05

0.19

0.37

0.09

0.47

0.51

1.46

7.62

14.34

0.46

0.50

0.50

0.21

0.39

0.49

0.29

0.40

0.27

0.85

Min

$\operatorname{Max}$

3.56

1

14.61

4.83

0.91

100

1

1

1

1

1

1

0.31

0

1 1

1

1


APPENDIX II: Logit analysis of the determinants of default for bonds underwritten by the internal securities departments and separate afmliates of commercial banks, 1925-1929." The dependent variable is "default," which has a mean of 0.22 , and equals one if the bond defaults on interest, principal, covenants, or sinking fund payments before 1940 and zero otherwise. (T-statistics are in parentheses.)

\begin{tabular}{|c|c|c|c|}
\hline Independent Variable & (i) & (ii) & (iii) \\
\hline $\begin{array}{l}\text { Indicator is } 1 \text { if the } \\
\text { underwriter is internal } \\
\text { securities department }\end{array}$ & $\begin{array}{c}0.62 \\
(2.10)\end{array}$ & $\begin{array}{c}0.64 \\
(2.00)\end{array}$ & $\begin{array}{c}0.80 \\
(2.07)\end{array}$ \\
\hline $\begin{array}{l}\text { Log of firm assets } \\
\text { in \$000 }\end{array}$ & - & $\begin{array}{c}-0.01 \\
(-0.87)\end{array}$ & $\begin{array}{c}0.06 \\
(0.50)\end{array}$ \\
\hline Log of firm age in years & - & $\begin{array}{c}-0.02 \\
(-0.18)\end{array}$ & $\begin{array}{c}-0.05 \\
(-0.46)\end{array}$ \\
\hline $\begin{array}{l}\text { Debt to assets ratio } \\
\text { before the issue }\end{array}$ & - & $\begin{array}{c}1.81 \\
(2.08)\end{array}$ & $\begin{array}{c}1.80 \\
(2.04)\end{array}$ \\
\hline $\begin{array}{l}\text { Maturity of bond in } \\
\text { years }\end{array}$ & - & $\begin{array}{c}-0.04 \\
(-1.84)\end{array}$ & $\begin{array}{r}-0.04 \\
(-1.70)\end{array}$ \\
\hline $\begin{array}{l}\text { Indicator is } 1 \text { if bank is a } \\
\text { national bank }\end{array}$ & - & - & $\begin{array}{c}0.62 \\
(1.69)\end{array}$ \\
\hline Log of bank age in years & - & - & $\begin{array}{c}-0.14 \\
(-0.52)\end{array}$ \\
\hline $\begin{array}{l}\text { Log of bank assets } \\
\text { in } \$ 000\end{array}$ & - & - & $\begin{array}{c}-0.11 \\
(-0.95)\end{array}$ \\
\hline $\begin{array}{l}\text { Includes indicators for } \\
\text { initial Moody's ratings } \\
\text { categories }\end{array}$ & Yes & Yes & Yes \\
\hline Number of Observations & 414 & 414 & 414 \\
\hline $\mathrm{Chi}^{2}$ for the Regression & 64.67 & 72.98 & 76.16 \\
\hline [p-value of $\mathrm{Chi}^{2}$ ] & {$[0.00]$} & {$[0.00]$} & {$[0.00]$} \\
\hline
\end{tabular}

- All specifications include indicators for (a) the year of issue, (b) one-digit SIC codes, (c) whether the issuer is a railroad, and (d) whether the issuer is a public utility. These coefficient estimates are not reported.

b Separate indicators are included for each Moody's rating category: that is, the first ratings indicator equals one if Moody's initially rated the bond Aaa and zero otherwise; the second ratings indicator equals one if the bond was rated $\mathrm{Aa}$, etc. 